\title{
Total ozone trends from 1979 to 2016 derived from five merged observational datasets - the emergence into ozone recovery
}

\author{
Mark Weber ${ }^{1}$, Melanie Coldewey-Egbers ${ }^{2}$, Vitali E. Fioletov ${ }^{3}$, Stacey M. Frith ${ }^{4}$, Jeannette D. Wild ${ }^{5,6}$, \\ John P. Burrows ${ }^{1}$, Craig S. Long ${ }^{5}$, and Diego Loyola ${ }^{2}$ \\ ${ }^{1}$ University of Bremen, Bremen, Germany \\ ${ }^{2}$ German Aerospace Center (DLR), Oberpfaffenhofen, Germany \\ ${ }^{3}$ Environment and Climate Change Canada, Toronto, Canada \\ ${ }^{4}$ Science Systems and Applications Inc., Lanham, MD, USA \\ ${ }^{5}$ NOAA/NCEP Climate Prediction Center, College Park, MD, USA \\ ${ }^{6}$ INNOVIM, Greenbelt, MD, USA
}

Correspondence: Mark Weber (weber@uni-bremen.de)

Received: 11 September 2017 - Discussion started: 13 September 2017

Revised: 8 January 2018 - Accepted: 9 January 2018 - Published: 14 February 2018

\begin{abstract}
We report on updated trends using different merged datasets from satellite and ground-based observations for the period from 1979 to 2016 . Trends were determined by applying a multiple linear regression (MLR) to annual mean zonal mean data. Merged datasets used here include NASA MOD v8.6 and National Oceanic and Atmospheric Administration (NOAA) merge v8.6, both based on data from the series of Solar Backscatter UltraViolet (SBUV) and SBUV-2 satellite instruments (1978-present) as well as the Global Ozone Monitoring Experiment (GOME)-type Total Ozone (GTO) and GOME-SCIAMACHY-GOME-2 (GSG) merged datasets (1995-present), mainly comprising satellite data from GOME, the Scanning Imaging Absorption Spectrometer for Atmospheric Chartography (SCIAMACHY), and GOME-2A. The fifth dataset consists of the monthly mean zonal mean data from ground-based measurements collected at World Ozone and UV Data Center (WOUDC). The addition of four more years of data since the last World Meteorological Organization (WMO) ozone assessment (2013-2016) shows that for most datasets and regions the trends since the stratospheric halogen reached its maximum ( $\sim 1996$ globally and $\sim 2000$ in polar regions) are mostly not significantly different from zero. However, for some latitudes, in particular the Southern Hemisphere extratropics and Northern Hemisphere subtropics, several datasets show small positive trends of slightly below $+1 \%$ decade $^{-1}$ that are barely statistically significant at the $2 \sigma$ uncertainty
\end{abstract}

level. In the tropics, only two datasets show significant trends of +0.5 to $+0.8 \%$ decade $^{-1}$, while the others show near-zero trends. Positive trends since 2000 have been observed over Antarctica in September, but near-zero trends are found in October as well as in March over the Arctic. Uncertainties due to possible drifts between the datasets, from the merging procedure used to combine satellite datasets and related to the low sampling of ground-based data, are not accounted for in the trend analysis. Consequently, the retrieved trends can be only considered to be at the brink of becoming significant, but there are indications that we are about to emerge into the expected recovery phase. However, the recent trends are still considerably masked by the observed large year-toyear dynamical variability in total ozone.

\section{Introduction}

The stratospheric ozone layer protects the biosphere from harmful UV radiation. One of the important measures that regulate the amount of UV radiation reaching the surface is the total column amount of ozone or, in short, total ozone, which is defined by the vertical integration of the ozone number density profile. As the ozone profile peaks in the lower stratosphere, total ozone is also representative of lower stratospheric ozone (from tropopause to about $27 \mathrm{~km}$ ). The strong decline in global total ozone observed throughout 
the 1980s and the discovery of the Antarctic ozone hole (Chubachi, 1984; Farman et al., 1985; Solomon et al., 1986) raised the awareness for the need to protect the ozone layer that culminated in the 1985 Vienna Convention to take action. The main cause for the severe ozone depletion was identified as halogen-containing substances also called ozonedepleting substances (ODSs), that are sufficiently long-lived to reach the stratosphere, releasing halogens that destroy ozone (e.g., Solomon, 1999). The Montreal Protocol and its amendments which were initiated in 1986 became a binding agreement on phasing out ODSs, that ultimately initiated a decline in stratospheric halogens about 10 years later (e.g., Anderson et al., 2000; Solomon et al., 2006).

Satellite and ground-based data revealed a dramatic total ozone column decline of about -3 to $-6 \%$ decade $^{-1}$ (dependent on latitude) throughout the 1980s until the mid1990s that was linked to observed ODS increases (Pawson et al., 2014, and references therein). In the Northern Hemisphere (NH), the lowest annual mean total column ozone levels occurred in 1993, resulting from enhanced stratospheric aerosol-related ozone loss after the major volcanic eruption of Mt. Pinatubo in 1991 a few years before the peak in stratospheric ODSs was reached (e.g., Chehade et al., 2014). In the late 1990s, annual mean total ozone increased rapidly in the $\mathrm{NH}$, faster than expected from the slow decrease in ODSs as a result of measures taken in response to the Montreal Protocol and its amendments. This rapid increase in the NH (Harris et al., 2008) revealed the important role of atmospheric dynamics, notably ozone transport via the Brewer-Dobson circulation that causes large variability on interannual and intra-annual timescales (e.g., Fusco and Salby, 1999; Randel et al., 2002; Dhomse et al., 2006; Harris et al., 2008; Weber et al., 2011).

Apart from the interannual variability, total ozone levels have remained globally stable since about the year 2000. The success of the Montreal Protocol agreement is thus undisputed as the earlier decline in total ozone was successfully stopped (Pawson et al., 2014). Since ODS levels (outside of the polar regions) are expected to decrease slowly at about one-third of the absolute rate of the earlier ODS increase (see Fig. 2 in Dhomse et al., 2006), it is expected that the onset of ozone recovery should be evident. There are two possible explanations as to why this has not been observed globally yet. Positive ozone trends are too small to be detected relative to the observed large variability and, secondly, ODSrelated ozone trends are in competition with trends due to climate feedbacks. The latter means total ozone trends are not necessarily congruent with stratospheric halogen trends; e.g., they have the same ratio of trends before and after the ODS peak as ODSs themselves. For instance, the observed increase of upper stratospheric ozone $(\sim 2 \mathrm{hPa})$ of about $2-$ $4 \%$ per decade since 2000 had about equal contributions from climate change and ODS changes as deduced from chemistry-climate models (see Figs. 2-20 and related references in Pawson et al., 2014).
Regular stratospheric ozone observations started with ground-based Dobson spectrophotometers in the mid-1920s (Dobson, 1968; Staehelin et al., 1998). The number of stations with regular Dobson spectrophotometer observations strongly increased after the International Geophysical Year (IPY) 1957/1958 (Dobson, 1968). First measurements of ozone from space occurred in 1970 with the launch of the BUV (Backscatter UV) spectrometer. Continuous measurements from space started at the end of 1978 with the Solar Backscatter UltraViolet (SBUV) and Total Ozone Mapping Spectrometer (TOMS) instruments (McPeters et al., 2013). Starting in 1995, the SBUV-2 and TOMS observations were complemented by the European Global Ozone Monitoring Experiment (GOME)-type instruments that in addition to ozone measure other important species $\left(\mathrm{NO}_{2}\right.$ and $\left.\mathrm{OClO}\right)$ relevant for stratospheric ozone chemistry (e.g., Burrows et al., 1999; Wagner et al., 2001; Richter et al., 2005).

Global and continuous ozone observations from space now span a time period of nearly 40 years. These observations now extend to about 20 years after the global stratospheric ODS peak occurring in approximately 1996 (or 16 years after the later ODS peak in polar regions). This is near the minimum number of years of observations required to obtain statistically significant ozone trends in the absence of other competing processes contributing to long-term ozone changes (Weatherhead et al., 2000).

This paper reports on updated total ozone trends by adding four more years of data (2013-2016) compared to results presented in the last World Meteorological Organization (WMO) ozone assessment (Pawson et al., 2014). As most satellite instruments have a limited lifetime of generally less than 10 years, long-term trends can only be investigated by using merged datasets. Currently, there are four different satellite datasets available; two of them rely on the series of SBUV instruments covering the period since 1979 (Frith et al., 2014; Wild and Long, 2017) and two datasets combine the European UV nadir sounders (GOME, GOME2, OMI, SCIAMACHY) starting from 1995 (Loyola et al., 2009; Kiesewetter et al., 2010; Weber et al., 2011; ColdeweyEgbers et al., 2015). These satellite datasets are complemented by a fifth dataset that is based on monthly mean zonal mean total ozone data derived from ground-based UV spectrometer data, mainly Dobsons and Brewers, which are collected at the WOUDC (World Ozone and UV Database Center) at Environment and Climate Change Canada (Fioletov et al., 2002). The regression analysis applied to these data is similar to that described in Chehade et al. (2014) and focuses on annual mean zonal mean data. The main difference to the earlier study is that we use in this paper five merged datasets, while in Chehade et al. (2014) only the GSG and SBUV MOD datasets were used. All datasets used here were updated up to and including 2016 (four more years added). In Chehade et al. (2014), the piecewise linear trends (PLTs) and equivalent effective stratospheric chlorine (EESC) term were fitted, while here only the independent linear trends (ILTs) 
before and after the turnaround in ODSs are considered for the reasons discussed in Sect. 3.2.

In Sect. 2, the five merged datasets are briefly described and followed in Sect. 3 by a description of the multiple linear regression (MLR) used in the trend analysis. Section 4 shows the results of total ozone trends in rather broad zonal bands (Southern Hemisphere and Northern Hemisphere extratropics and tropics) that are commonly used for ozone profile trends (Steinbrecht et al., 2017). This will allow us to look at the consistency between lower stratospheric ozone (derived from profile observations) and total ozone trends. In Sect. 5, latitude-dependent annual mean trends are presented and discussed. Results will be also shown in Sect. 6 for selected months during polar spring as recovery of Antarctic ozone levels in September has been recently reported by Solomon et al. (2016). A summary and final remarks are given in Sect. 7 .

\section{Total ozone datasets}

A total of five merged and homogenized datasets are used in this study. There are two different versions of merged datasets from the series of SBUV and SBUV-2 satellite instruments (NASA SBUV MOD v8.6 and National Oceanic and Atmospheric Administration (NOAA) SBUV Merge v8.6) that have been operated continuously since the late 1970s. Two merged datasets are mainly based on the series of European satellite spectrometers GOME, Scanning Imaging Absorption Spectrometer for Atmospheric Chartography (SCIAMACHY), and GOME-2A which use different retrieval algorithms and slightly different merging approaches (University of Bremen GSG and ESA/DLR GTO datasets). Both datasets cover the period from 1995 to today. The fifth dataset is the monthly mean zonal mean data from the network of ground-based Brewers, Dobsons, SAOZ (Système d'Analyse par Observations Zénithales), and filter instruments collected at the WOUDC (Fioletov et al., 2002). The data sources are summarized in Table 1 and the various datasets are briefly described in the following subsections.

\subsection{NASA SBUV MOD v8.6}

The NASA Merged Ozone Data (MOD) time series is constructed using data from the Nimbus 4 BUV and Nimbus 7 SBUV instruments and from six NOAA SBUV-2 instruments numbered 11, 14, and 16-19 (Frith et al., 2014). The instruments are of similar design, and measurements from each are processed using the same v8.6 retrieval algorithm (Bhartia et al., 2013). The version 8.6 data contains ozone profiles in mixing ratio on pressure levels and in Dobson units on layers. The total ozone is then provided as the sum of the layer data.

To maintain consistency over the entire time series, the individual instrument records are analyzed with respect to each other and absolute calibration adjustments are applied as needed based on comparison of radiance measurements during periods of instrument overlap (DeLand et al., 2012). Data from NOAA-9 SBUV-2 and data taken as the Equator crossing time as the satellite approaches the terminator are of lesser quality and are excluded from the MOD composite (DeLand et al., 2012; Kramarova et al., 2013). See Frith et al. (2014) for a detailed description of the data used in MOD.

For total ozone, differences between SBUV measurements computed during the overlap periods are typically less than the differences between any given instrument and external data sources (Labow et al., 2013; McPeters et al., 2013; Frith et al., 2014). Therefore, no additional adjustments to the individual instrument measurements are applied, as the adjustments are generally smaller than the inherent instrument uncertainty. Moreover, there is no physical rationale to identify one instrument as better than the others, so MOD comprises all available data. During periods of overlap, data from multiple instruments are averaged.

\subsection{NOAA SBUV Merge v8.6}

The NOAA SBUV Merge v8.6 is based on the same ozone profile data retrieved with the v8.6 retrieval algorithm as described in Sect. 2.1. There are many methods by which the data from the various satellites can be combined. Averaging data from all available satellites in a common period as done in NASA SBUV MOD (Sect. 2.1) is one method to create a combined dataset. However, characteristics of the measurement (e.g., time of measurement) are lost by this averaging. Another method is to identify a representative satellite for each time period as is done in the NOAA-SBUV Merge dataset. Additionally, it must be determined if the data from the individual satellites can be adjusted to improve intersatellite consistency.

Kramarova et al. (2013) shows that SBUV version 8.6 ozone profile data from individual satellites after a meticulous cross-instrument calibration can differ by as much as $5 \%$ in various layers of the profile from data from MLS on UARS and Aura, and SAGE II due to bias differences between the instruments and potential diurnal issues above $4 \mathrm{hPa}$. Recent studies (Wild and Long, 2017) show similar differences between NOAA-18 and NOAA-19. The NOAASBUV dataset incorporates some corrections to individual satellite profiles. In the later period of NOAA-16 to -19 , the overlaps are long, and each satellite can be compared and adjusted directly to NOAA-18 removing the small intersatellite biases (Wild and Long, 2017).

Strong drifts in the early satellites and poor quality of NOAA-9 and NOAA-14 data can create unphysical trends when a successive head-to-tail adjustment scheme is used in the early period (Tummon et al., 2015). The current NOAASBUV dataset does not adjust the Nimbus-7 or NOAA-11 data and does not include the NOAA-9 ascending node. Only the NOAA-9 descending data are adjusted to fit between the 
Table 1. Start year and source of merged total ozone datasets.

\begin{tabular}{|c|c|c|}
\hline Dataset & Start year & Source \\
\hline NASA MOD v8.6 & 1970 & http://acdb-ext.gsfc.nasa.gov/Data_services/merged/ \\
\hline NOAA SBUV Merge v8.6 & 1978 & ftp://ftp.cpc.ncep.noaa.gov/SBUV_CDR/ \\
\hline GSG & 1995 & http://www.iup.uni-bremen.de/gome/wfdoas \\
\hline GTO & 1995 & http://atmos.eoc.dlr.de/gome/gto-ecv.html \\
\hline WOUDC & 1964 & http://woudc.org/archive/Projects-Campaigns/ZonalMeans/ \\
\hline
\end{tabular}

ascending and descending nodes of NOAA-11. NOAA-14 data do not appear in the final dataset, but they are used to enable a fit of NOAA-9 descending to NOAA-11 descending where no overlap exists (Wild and Long, 2017).

The total ozone product is calculated so that it remains the sum of the adjusted profile layer data. When the resulting profiles are added, many of the profile adjustments are offset. The final total ozone product is altered by less than $1 \%$, and in most cases by less than $0.5 \%$ from the original single satellite dataset.

\subsection{GSG}

The merged GOME, SCIAMACHY, and GOME-2A (GSG) total ozone time series (Kiesewetter et al., 2010; Weber et al., 2011, 2016) consists of total ozone data that were retrieved using the University of Bremen weighting function DOAS (WFDOAS) algorithm (Coldewey-Egbers et al., 2005; Weber et al., 2005). The most recent modification was in the GOME-2A data record. In the WFDOAS retrieval, the change in the GOME-2A instrument function with time (De Smedt et al., 2012) was accounted for by convolving ozone cross-section data with instrument function derived from daily spectral solar observations with the same instrument. Without such a correction, a drift of about $+1.5 \%$ decade $^{-1}$ becomes apparent.

The SCIAMACHY and GOME-2A observations were successively adjusted for the apparent offsets to be continuous with the original GOME data. Biases (offsets) were determined as a function of latitude in steps of $1^{\circ}$ using monthly zonal means and smoothed over $10^{\circ}$ latitudes. Drift corrections were not applied here.

There appears a drop of the original GOME-2 data record during the 2009-2011 period relative to SCIAMACHY, which seems to be larger than the overall bias between two datasets (see Fig. 1 in Weatherhead et al., 2017). However, the very large overlap period from 2007 to 2012 between SCIAMACHY and GOME-2A was an advantage and no further corrections beyond the latitude-dependent biases were needed to adjust GOME-2A. Due to this temporary drop in the GOME-2A data, the SCIAMACHY data became the preferred choice in the merged (GSG) dataset during the overlap period (2007-2011). In comparison, the overlap period for SCIAMACHY and GOME was very short, less than 10 months (2002-2003).
The merged GSG data are in very good agreement with WOUDC zonal mean monthly data (update from Fioletov et al., 2002, and Sect. 2.5) as shown in Fig. 1 of Weatherhead et al. (2017).

\subsection{GTO}

The GOME-type Total Ozone Essential Climate Variable (GTO-ECV) data record (Coldewey-Egbers et al., 2015) has been created within the framework of the European Space Agency's Climate Change Initiative (ESA-CCI) ozone project. Observations from GOME, SCIAMACHY, OMI, and GOME-2A were combined into a single homogeneous record that covers the period from July 1995 to December 2016. The total ozone columns were retrieved using the GOME-type Direct FITting (GODFIT) version 3 algorithm (Lerot et al., 2014). In order to correct for small remaining intersensor biases and temporal drifts, GOME, SCIAMACHY, and GOME-2A measurements were adjusted to OMI before merging into a cohesive record. Appropriate correction factors were determined during overlap periods as a function of latitude and time. Furthermore, special emphasis was placed on the analysis of spatiotemporal sampling differences intrinsic to the satellite data and on their impact on the merged product.

Ground-based validation using Brewer, Dobson, and UVvisible instruments has shown that the GTO-ECV level-3 data record is of the same high quality as the individual level-2 data products that constitute it. Both absolute agreement and long-term stability are excellent with respect to the ground reference for almost all latitudes (Coldewey-Egbers et al., 2015; Koukouli et al., 2015) and well within the Global Climate Observing System (GCOS) target requirements (Mason and Simmons, 2011). A small number of outliers were found mostly related to sampling differences that could not be completely eradicated (see Figs. 10 and 11 in Coldewey-Egbers et al., 2015).

\subsection{WOUDC data}

The WOUDC ground-based zonal mean dataset (Fioletov et al., 2002) was formed from ground-based measurement by Dobson, Brewer, and SAOZ instruments, and filter ozonometers available from the WOUDC. Over the polar night areas, Dobson and Brewer moon measurements as well as 
integrated ozonesonde profiles were used. The data were screened for erroneous and unreliable measurements. The overall performance of the ground-based network was discussed by Fioletov et al. (2008).

At the next step, ground-based measurements were compared with ozone "climatology" (monthly means for each point of the globe) estimated from Nimbus-7 Total Ozone Mapping Spectrometer (N7 TOMS) satellite data for 19781989. Then, for each station and for each month, the deviations from the climatology were calculated, and the belt's value for a particular month was estimated as a mean of these deviations. The calculations were done for $5^{\circ}$ latitudinal belts. In order to take into account various densities of the network across regions, the deviations of the stations were first averaged over $5^{\circ}$ by $30^{\circ}$ cells, and then the belt mean was calculated by averaging these first sets of averages over the belts. Until this point, the data in the different $5^{\circ}$ belts were based on different stations (i.e., were considered independent). However, the differences between nearby belts are small. Therefore, the errors of the belt's average estimations can be reduced by using some smoothing or approximation. The zonal means were then approximated by zonal spherical functions (Legendre polynomials of cosines of the latitude) to smooth out spurious variations. The merged satellite and the WOUDC datasets were compared again recently and demonstrated good agreement (Chiou et al., 2014). Estimates based on relatively sparse ground-based measurements, particularly in the tropics and Southern Hemisphere, may not always reproduce monthly zonal fluctuations well. However, seasonal (and longer) averages can be estimated with a precision comparable with satellite-based datasets $(\sim 1 \%)$.

\subsection{Data preparation}

The MLR is applied to annual mean data. In this case, no corrections are needed to account for autoregression that is evident in monthly mean time series (e.g., Weatherhead et al., 1998; Dhomse et al., 2006; Vyushin et al., 2007, 2010). Annual means were calculated from the monthly mean data that were all provided as zonal means in steps of $5^{\circ}$ latitude. Annual mean data were only included for those years where at least $80 \%$ of months in a given year were available (10 months). The SBUV merged data have data gaps of up to 3 years following the Pinatubo eruption and 1-2 years following El Chichón. Broader zonal means (e.g., for 35-60 $\mathrm{N}$ ) were then calculated by area weighting the $5^{\circ}$ annual mean values contained in the bands. At least $80 \%$ of the $5^{\circ}$ zonal bands are required to make the broadband average.

All annual mean zonal mean time series were corrected for possible biases between them by subtracting the 1998-2008 average from each dataset, and later the mean of decadal 1998-2008 averages from all datasets were added back to each dataset. That way the original values of all time series are nearly preserved but the bias is reduced as is the case when using ozone anomalies.
The bias-corrected GSG and GTO datasets were both extended from 1995 back to 1979 using the bias-corrected NOAA data, so that MLR was always applied to the full time period starting in 1979 for all datasets. This way one ensures that all terms other than the trend terms are determined from the full time period. The NOAA data were used here as the NASA data have larger data gaps.

\section{Multiple linear regression}

In this section, the MLR equation and the various explanatory variables used are briefly summarized (Sect. 3.1), followed by a discussion on the various choices of trend terms, e.g., independent linear trends before and after the turnaround of the stratospheric halogen (preferred choice in this study), hockey stick, or EESC curve (Sect. 3.2).

\subsection{MLR and explanatory variables}

Total ozone trends are here derived from annual mean zonal mean ozone data using the MLR equation given by

$$
\begin{aligned}
y(t)= & a_{1} \cdot X_{1}(t)+b_{1} \cdot X_{1}(t)\left(t_{0}-t\right)+a_{2} \cdot X_{2}(t) \\
& +b_{2} \cdot X_{2}(t)\left(t-t_{0}\right)+\alpha_{\text {sun }} \cdot S(t)+\alpha_{\mathrm{qbo50} 0} \cdot Q_{50}(t) \\
& +\alpha_{\mathrm{qbo} 10} \cdot Q_{10}(t)+\alpha_{\text {ElChichón }} \cdot A_{1}(t) \\
& +\alpha_{\text {Pinatubo }} \cdot A_{2}(t)+\alpha_{\mathrm{ENSO}} \cdot E(t)+P(t),
\end{aligned}
$$

where $y(t)$ is the annual mean total ozone time series and $t$ the year of observations. The coefficients $b_{1}$ and $b_{2}$ are the linear trends before and after the turnaround year $t_{0}$ when the stratospheric halogen reached its maximum abundance. In order to make both trends independent of each other (or disjoint), two $y$ intercepts ( $a_{1}$ and $a_{2}$ ) are determined. The multiplication of the independent variable $t$ with $X_{i}(t)$ in the first four terms of Eq. (1) describes mathematically that the first two terms only apply to the period before and the third and fourth terms to the period after the turnaround year $t_{0}$. $X_{1}(t)$ and $X_{2}(t)$ are given by

$$
X_{1}(t)= \begin{cases}1 & \text { if } t \leq t_{0} \\ 0 & \text { if } t>t_{0}\end{cases}
$$

and

$$
X_{2}(t)=\left\{\begin{array}{ll}
0 & \text { if } t \leq t_{0} \\
1 & \text { if } t>t_{0}
\end{array},\right.
$$

respectively. From the calculation of the EESC, this maximum was reached at about the year $t_{0}=1996$ (Newman et al., 2007) and some years later $\left(t_{0} \sim 2000\right)$ in the polar regions (Newman et al., 2006, 2007).

Other main factors contributing to ozone variability and included in the MLR are the quasi-biennial oscillation (QBO), 11-year solar cycle, El Niño-Southern Oscillation (ENSO), 
and volcanic aerosol. The use of QBO terms (50 and $10 \mathrm{hPa}$ ) allows a phase shift in the quasi-cyclic variation of total ozone with respect to QBO variations. The contributions from the 11-year solar cycle and QBO are in common use in total ozone MLR (e.g., Staehelin et al., 2001; Reinsel et al., 2005).

Aerosol terms related to the major volcanic eruptions like El Chichón (1982) and Mt. Pinatubo (1991) are important, in particular, to describe the large ozone decrease observed in the early 1990s. The volcanic aerosol effect from the El Chichón eruption (1982) is independently treated in the MLR from the effect of the Mt. Pinatubo eruption (1991). The dynamical responses to the major volcanic events were quite different. While Mt. Pinatubo led to enhanced ozone depletion, the Southern Hemisphere (SH) extratropical total ozone rather increased as a result of a particular dynamics condition following the El Chichón event (Schnadt Poberaj et al., 2011; Aquila et al., 2013; Dhomse et al., 2015). For El Chichón, the stratospheric aerosol optical depth (SAOD) at $550 \mathrm{~nm}$ from Sato et al. (1993) is used as the explanatory variable, while newer data from the WACCM model (Mills et al., 2016) are used for the period after 1990 that is dominated by the Mt. Pinatubo major volcanic eruption and also covers the series of more minor volcanic eruptions from the last decade. Though smaller, these eruptions injected sufficient amounts of aerosols into the stratosphere to affect Antarctic ozone (Solomon et al., 2016; Ivy et al., 2017). The SAOD from Sato et al. (1993) is derived from satellite observations and includes column amounts that extend down to about $15 \mathrm{~km}$. The same data from the WACCM model represent the column amount down to the tropopause and may differ significantly from the former. The WACCM data are only available for the period after 1990 (Mills et al., 2016) and are used for the "Pinatubo" term, while for the period before 1990 the Sato et al. (1993) SAOD is used.

In the SBUV data records, there are for some years not a sufficient number of months and/or $5^{\circ}$ latitude bands available, and no annual means are calculated. If annual means for the years 1982 and 1983 are missing, the "El Chichón" term is not used in the MLR; similarly, if all years are missing from 1991 to 1994, the "Pinatubo" term is excluded in the MLR.

The MLR equation without the $P(t)$ term, Eq. (1), is considered the standard MLR that is commonly applied for determining trends from ozone profile data (e.g., Bourassa et al., 2014, 2017; Harris et al., 2015; Tummon et al., 2015; Sofieva et al., 2017; Steinbrecht et al., 2017). The extra term $P(t)$ in Eq. (1) accounts for other factors of dynamical variability that have been used in different combinations and definitions (e.g., accumulated, time-lagged) in the past. It includes contributions from the Arctic Oscillation (AO) and the Brewer-Dobson circulation (BDC) (e.g., Reinsel et al., 2005; Mäder et al., 2007; Chehade et al., 2014). The BDC terms are usually described by the eddy heat flux at $100 \mathrm{hPa}$ that is considered a main driver of the BDC (Fusco and Salby, 1999;
Randel et al., 2002; Weber et al., 2011). The additional term $P(t)$ can be described as follows:

$$
\begin{aligned}
P(t)= & \alpha_{\mathrm{AO}} \cdot \mathrm{AO}(t)+\alpha_{\mathrm{BDCn}} \cdot \operatorname{BDCn}(t) \\
& +\alpha_{\mathrm{BDCs}} \cdot \operatorname{BDCs}(t) .
\end{aligned}
$$

There are different terms for BDC in each hemisphere indicated by indices $\mathrm{s}(\mathrm{SH})$ and $\mathrm{n}(\mathrm{NH})$. The eddy heat flux is derived from daily ECMWF ERA-Interim (ERA-I) reanalysis data (Dee et al., 2011). For each day, the area-weighted mean of the $100 \mathrm{hPa}$ eddy heat flux between the 45 and $75^{\circ}$ latitudes separately for each hemisphere is calculated and the monthly mean time series derived (Weber et al., 2011). In the MLR applied to annual mean data, the winter averaged eddy heat flux is used as an independent variable. The winter averages, $\operatorname{BDCn}(t)$ and $\operatorname{BDCs}(t)$, are derived by taking the mean from September to April of the previous year in the $\mathrm{NH}$ and from March to October in the SH, respectively, if not stated otherwise. For all other terms, annual mean proxy time series are used in the MLR.

Not all terms of $P(t)$ are used in the regression since they are not entirely uncorrelated (see, for instance, Mäder et al., 2010; Weber et al., 2011; Chehade et al., 2014). Individual terms in Eq. (4) are only retained in the regression if the absolute value of the coefficient exceeds its $2 \sigma$ uncertainty and remains robust for any combination of terms from Eq. (4). For example, even though the Antarctic Oscillation (AAO), the counterpart of the $\mathrm{AO}$ in the $\mathrm{NH}$, provides an important ozone feedback mechanism and is strongly related to the Antarctic ozone hole (e.g., Thompson and Solomon, 2002), in this analysis, this term is not robust as its significance strongly depends on whether the BDC's term is added or not.

Without the use of some additional terms contained in Eq. (4), the MLR is not able to model the large excursions in some years, e.g., 2002 in the SH or 2011 in the NH extratropics. The various explanatory variables and the sources of proxy time series are summarized in Table 2 .

\subsection{Choice of trend terms}

In Eq. (1), the two linear trends before and after the ODS turnaround time $t_{0}$ are not continuous and are independent from each other (Pawson et al., 2014); thus, we call this approach an ILT. All other terms apply to the complete time period. The earliest studies of ozone recovery looked at the statistical significance of the trend after $t_{0}$ relative to the trend before $t_{0}$. The initial trend and trend change term are frequently called hockey stick or PLTs (Harris et al., 2008) and are mathematically equivalent to Eq. (1) without the second $y$ intercept or $a_{2}=0$. Several studies showed that the total ozone trend change in the extratropics is statistically significant (e.g., Reinsel et al., 2005; Harris et al., 2008; Steinbrecht et al., 2011; Mäder et al., 2010; Nair et al., 2013; Chehade et al., 2014; Zvyagintsev et al., 2015) and this fact is consid- 
Table 2. Sources of explanatory variables/proxy time series used in the MLR.

\begin{tabular}{|c|c|c|}
\hline Variable & Proxy & Source \\
\hline$S(t)$ & $\begin{array}{l}\text { Bremen composite } \mathrm{Mg} \text { II index } \\
\text { (Snow et al., 2014) }\end{array}$ & http://www.iup.uni-bremen.de/UVSAT/Datasets/mgii \\
\hline $\mathrm{QBO}_{50}(t), \mathrm{QBO}_{10}(t)$ & $\begin{array}{l}\text { Singapore wind speed at } 50 \text { and } 10 \mathrm{hPa} \\
\text { (update from Naujokat, 1986) }\end{array}$ & http://www.geo.fu-berlin.de/met/ag/strat/produkte/qbo/qbo.dat \\
\hline$E(t)$ & $\begin{array}{l}\text { MEI (ENSO) index } \\
\text { (Wolter and Timlin, 2011) }\end{array}$ & https://www.esrl.noaa.gov/psd/enso/mei/ \\
\hline $\mathrm{AO}(t), \operatorname{AAO}(t)$ & $\begin{array}{l}\text { Antarctic Oscillation (AAO), Arctic } \\
\text { Oscillation (AO) }\end{array}$ & $\begin{array}{l}\text { http://www.cpc.ncep.noaa.gov/products/precip/CWlink/daily_ } \\
\text { ao_index/teleconnections.shtml }\end{array}$ \\
\hline$A_{1}(t)$ & $\begin{array}{l}\text { Stratospheric aerosol depth at } 550 \mathrm{~nm} \\
(t<1990) \\
\text { (update from Sato et al., 1993) }\end{array}$ & $\begin{array}{l}\text { https://data.giss.nasa.gov/modelforce/strataer/tau.line_2012. } \\
\text { 12.txt }\end{array}$ \\
\hline$A_{2}(t)$ & $\begin{array}{l}\text { Stratospheric aerosol depth at } 550 \mathrm{~nm} \\
\text { from the WACCM model }(t \geq 1990) \\
\text { (Mills et al., 2016) }\end{array}$ & http://dx.doi.org/10.5065/D6S180JM \\
\hline
\end{tabular}

ered proof that the Montreal Protocol and amendments phasing out ODSs have been working (Pawson et al., 2014).

The third possible choice is the use of the EESC curve replacing the linear regression terms (Harris et al., 2008; Mäder et al., 2010; Frossard et al., 2013; Nair et al., 2013; Chehade et al., 2014; Zvyagintsev et al., 2015). In the last WMO ozone assessment (Pawson et al., 2014), the evolution of total ozone was reported to be largely consistent with the range given by the ensemble of climate models accounting for ODS changes. The drawback is that the long-term trend (from the fitted EESC curve) after the ODS turnaround $t_{0}$ is fixed relative to the trend before. The EESC or stratospheric halogen curve indicates that the expected recovery rate in the extratropics is about one-third of the absolute declining rate before $t_{0}$ (Dhomse et al., 2006). Since the post-ODS peak trend is smaller, the EESC fit will be mainly determined by the fit in the declining phase before $t_{0}$ and thus provides little information on trends after the ODS peak (for illustration, see Fig. 1 and Kuttippurath et al., 2015).

The exact shape of the EESC curve as a function of altitude and latitude is highly uncertain. In most regressions, only one representative EESC curve for the extratropics and polar regions, respectively, is fitted as calculated from tropospheric emissions assuming a certain age-of-air distribution (Newman et al., 2007). Since the EESC as well as the linear trend terms (ILTs, PLTs) are the only "low"-frequency terms in the MLR (while others, such as aerosols, are more or less cyclic or spiky), any low-frequency contributions to ozone changes other than ODSs will be also fitted by these terms. In the upper stratosphere, the impact of stratospheric cooling due to climate change and lower ODSs contributes roughly equally to recent ozone increases (Pawson et al., 2014). Thus, there is no reason to assume that the net ozone trends, preand post-ODS peak, from all low-frequency forcings will follow the EESC, which represents only chemical forcing from ODS change. ILT and, to some extent, PLT better represent

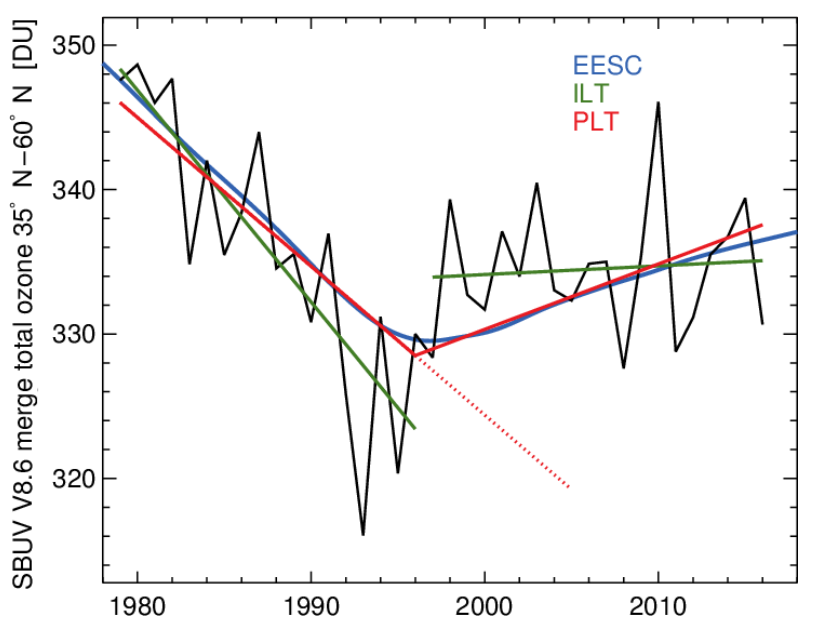

Figure 1. Illustration of different choices of trend terms commonly used in MLR applied to total ozone. Blue: EESC; red: PLTs before and after $t_{0}=1996$, also called hockey stick; green: ILTs. The black curve shows the NH total ozone time series from NOAA SBUV v8.6. The red dotted line indicates that the PLT is mathematically equivalent to using a trend change term in the MLR. The injection point is the point where the trend change terms starts (here, in the year 1996). All fits were done using only the linear regression terms in Eq. (1) or, alternatively, the EESC curve replacing linear regression terms; see discussion in main text.

the ozone change from all low-frequency forcings, but disentangling these signals is difficult.

Regardless of the use of trend terms (ILTs, PLTs, or EESC) the question arises as to when we will see the emergence of ozone recovery; i.e., ozone trends become positive and statistically significant beyond the year-to-year variability. In this study, we prefer the use of ILTs over the hockey stick (PLTs) for the following reasons. The injection point of the PLT (see Fig. 1) in 1996 is quite close to the ozone minimum related to the Mt. Pinatubo major volcanic eruption in 


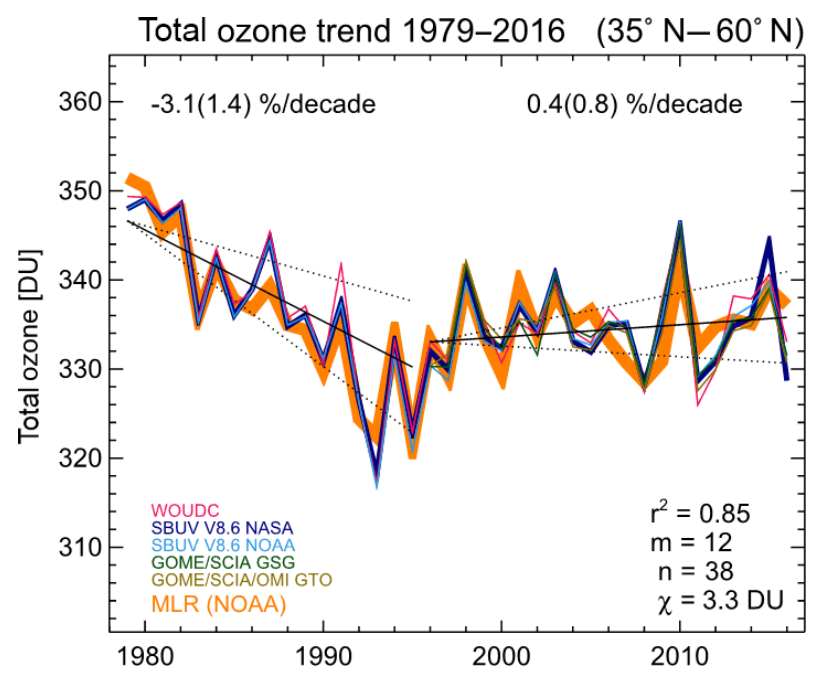

Figure 2. NH annual mean total ozone time series of five biascorrected merged datasets in the $35-60^{\circ} \mathrm{N}$ latitude band ( $\mathrm{NH}$ extratropics). The thick orange line is the result from applying MLR (Eq. 1) to the NOAA time series. In addition to the standard MLR, $\mathrm{AO}$ and BDC-N terms are included (see Eq. 4). $n$ is the number of data (years) used in the MLR and $m$ the number of parameters fitted. The square of the correlation between observations and MLR is given by $r^{2} \cdot \chi^{2}$ is the sum square of the time series minus MLR divided by the degrees of freedom $(n-m)$. The solid lines indicate the linear trends before and after the ODS peak, respectively. The dotted lines show the $2 \sigma$ uncertainty of the MLR trend estimates. Trend numbers are indicated for the pre- and post-ODS peak periods in the top part of the plot. Numbers in parentheses are the $2 \sigma$ trend uncertainty.

1991/1992. This injection point may be lower if the aerosol effect is not properly modeled by the MLR, which will likely enhance the trend after the injection point. A second important point is that the SBUV datasets have larger gaps as a result of applying a stricter filtering in the data following the major eruptions from El Chichón and Pinatubo. Volcanically enhanced aerosols interfere with the ozone retrieval and lead to higher uncertainties (Frith et al., 2014). As a consequence, the determination of the injection point of a PLT has larger uncertainties and it may affect both trends before and after $t_{0}$.

\section{Trends in broad zonal bands}

In Figs. 2 and 3, the five bias-corrected merged time series are shown for the extratropical $35-60^{\circ}$ zonal bands in the Northern Hemisphere and Southern Hemisphere, respectively. In the NH, the results from the MLR are only shown for the NOAA dataset and are indicated by the orange line. In the SH, the MLR results from the WOUDC data are indicated. In general, the agreement between the datasets are better than those with the MLR results, but also the MLR works reasonably well, explaining about $85 \%$ of the variance in the

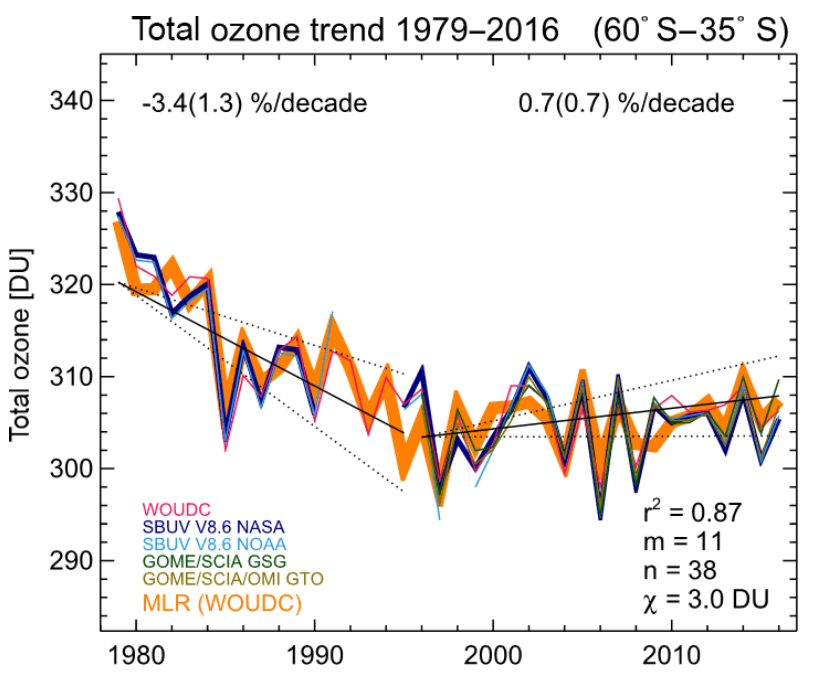

Figure 3. Same as Fig. 2 but for the $35-60^{\circ} \mathrm{S}$ zonal band (SH extratropics) and MLR applied to WOUDC ground-based data. Standard MLR plus BDC-S term was applied to the WOUDC data.

time series. There is overall a high consistency between all datasets in the extratropics. The standard MLR plus AO and $\mathrm{NH}$ BDC terms were used in the $\mathrm{NH}$, while in the SH only the SH BDC term was added.

Before 1997, total ozone trends in the extratropical belts between 35 and $60^{\circ}$ in each hemisphere were about $-3 \pm$ $1.5(2 \sigma) \% \mathrm{decade}^{-1}$. The trends changed to about zero to $+0.5 \%$ decade $^{-1}$ after the ODS peak in the extratropics. The recent trends are mostly statistically not significantly different from a zero trend, meaning total ozone levels remained stable in the extratropics over the last 20 years (1996-2016). Nevertheless, the trend change is significant and it confirms the conclusions from the last WMO ozone assessment that the ODS-related decline was successfully stopped (Pawson et al., 2014).

Table 3 summarizes the post-ODS peak trends for the five datasets considered here. In the $\mathrm{NH}$ extratropics, most data show a near-zero trend. In the SH extratropics, trends are positive and slightly larger than in the NH. The GSG, GTO, and WOUDC datasets indicate a positive trend of $0.7 \%$ decade $^{-1}$ here, barely reaching the $2 \sigma$ uncertainty level. Except for the NASA dataset, all datasets show a positive trend of $+0.5 \%$ decade $^{-1}$ or more in the SH.

Figures 4 and 5 ( $\mathrm{NH}$ and $\mathrm{SH}$, respectively) show how the post-ODS peak trend changed during the last decade by adding more years of observations since 2006. Up until 2010, the linear trends in the $\mathrm{NH}$ were at about $+1 \%$ decade $^{-1}$ with an uncertainty just less than $2 \%(2 \sigma)$. With additional years after 2010 , trends lowered to about $+0.5 \%$ decade $^{-1}$. The uncertainty is now reduced to slightly below $1 \%$ decade $^{-1}$. This means that a trend of $1 \%$ decade $^{-1}$ could be observed after 20 years of observations following the ODS peak. The below-average annual mean $\mathrm{NH}$ total ozone in 2016 is linked 
Table 3. The 1979-1996 and 1997-2016 annual mean total ozone trends in broad zonal bands. Uncertainties are provided for $2 \sigma$ and trends in bold indicate statistical significance. $r^{2}$ is the squared Pearson correlation and $\chi$ the residual defined as $\chi^{2}=\sum_{i}\left(\operatorname{obs}_{i}-\bmod _{i}\right)^{2} /(n-m)$, where $\operatorname{obs}_{i}$ are the observations and $\bmod _{i}$ the MLR model, $n$ the number of data (years) in the time series, and $m$ the number of parameters fitted. In the NH, standard MLR plus AO and BDC-N terms were used; in the SH and tropics, standard MLR plus the SH BDC term were used. DU indicates Dobson units.

\begin{tabular}{|c|c|c|c|c|c|c|c|}
\hline Zonal bands & MLR & & NASA & NOAA & GSG & GTO & WOUDC \\
\hline $35-60^{\circ} \mathrm{N}$ & standard $+\mathrm{AO}+\mathrm{BDC}-\mathrm{N}$ & trend $>1996\left(\%\right.$ decade $\left.^{-1}\right)$ & $+0.2(8)$ & $+0.4(8)$ & $+0.2(8)$ & $-0.1(8)$ & $+0.2(8)$ \\
\hline \multirow[t]{3}{*}{ Annual } & & trend $\leq 1996\left(\%\right.$ decade $\left.^{-1}\right)$ & $-2.8(15)$ & $-3.1(14)$ & - & - & $-2.8(15)$ \\
\hline & & $r^{2}$ & 0.83 & 0.85 & 0.84 & 0.85 & 0.83 \\
\hline & & $\chi(\mathrm{DU})$ & 3.5 & 3.3 & 3.3 & 3.2 & 3.6 \\
\hline $20^{\circ} \mathrm{S}-20^{\circ} \mathrm{N}$ & standard + BDC-S & trend $>1996\left(\%\right.$ decade $\left.^{-1}\right)$ & $+0.1(3)$ & $+0.2(3)$ & $+0.8(4)$ & $0.0(4)$ & $+0.5(5)$ \\
\hline \multirow[t]{3}{*}{ Annual } & & trend $\leq 1996\left(\%\right.$ decade $\left.^{-1}\right)$ & $-0.3(6)$ & $-0.5(6)$ & - & - & $+0.2(8)$ \\
\hline & & $r^{2}$ & 0.87 & 0.87 & 0.85 & 0.83 & 0.77 \\
\hline & & $\chi(\mathrm{DU})$ & 1.1 & 1.2 & 1.3 & 1.3 & 1.7 \\
\hline $35-60^{\circ} \mathrm{S}$ & standard + BDC-S & trend $>1996\left(\%\right.$ decade $\left.^{-1}\right)$ & $+0.3(7)$ & $+0.6(8)$ & $+0.7(7)$ & $+0.6(6)$ & $+0.7(7)$ \\
\hline \multirow[t]{3}{*}{ Annual } & & trend $\leq 1996\left(\%\right.$ decade $\left.^{-1}\right)$ & $-3.6(14)$ & $-3.4(14)$ & - & - & $-3.4(13)$ \\
\hline & & $r^{2}$ & 0.89 & 0.89 & 0.90 & 0.91 & 0.87 \\
\hline & & $\chi(\mathrm{DU})$ & 3.0 & 3.1 & 2.7 & 2.6 & 3.0 \\
\hline
\end{tabular}

Bold numbers indicate statistical significance at $2 \sigma$.

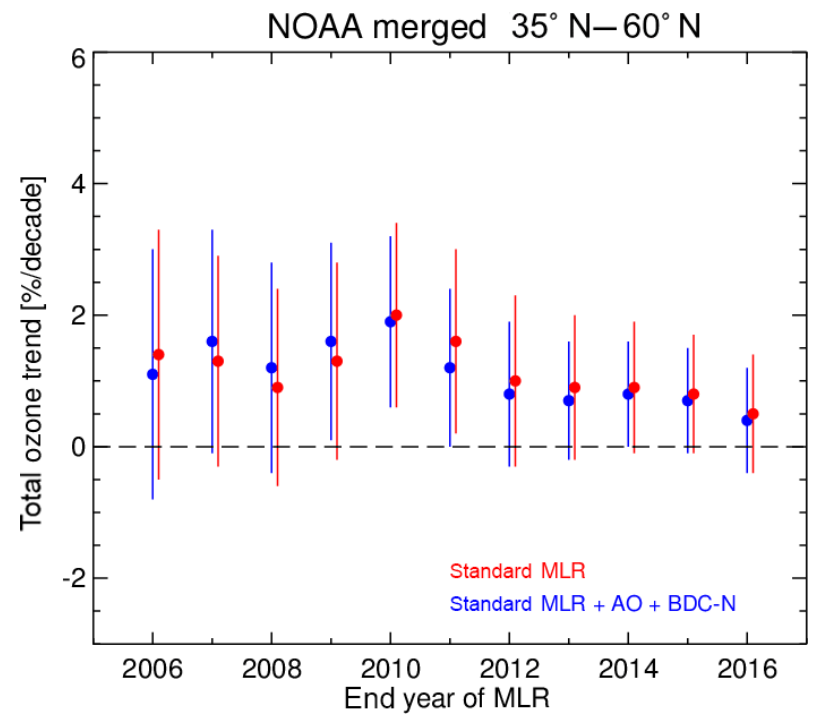

Figure 4. The dependence of the post-ODS peak trends in the NH extratropics from the end year in the MLR. The vertical bars show the $2 \sigma$ uncertainties of the trends. Red symbols are the results from the standard MLR fit (Eq. 1 with $P(t)=0$ ) and blue from the extended MLR that includes the AO and NH BDC terms (see Eq. 4).

to the severe Arctic ozone depletion in the same year (Manney and Lawrence, 2016) and related to the anomalous QBOinduced meridional circulation changes (Osprey et al., 2016; Tweedy et al., 2017). This resulted in a drop of the 1997$2016 \mathrm{NH}$ ozone trend down to $+0.4 \%$ decade $^{-1}$ (compared to $+0.6 \%$ decade $^{-1}$ ending in 2015). The trend estimates are somewhat dependent on the end value in the time series. In 2010, NH extratropical ozone levels were unusually high (see

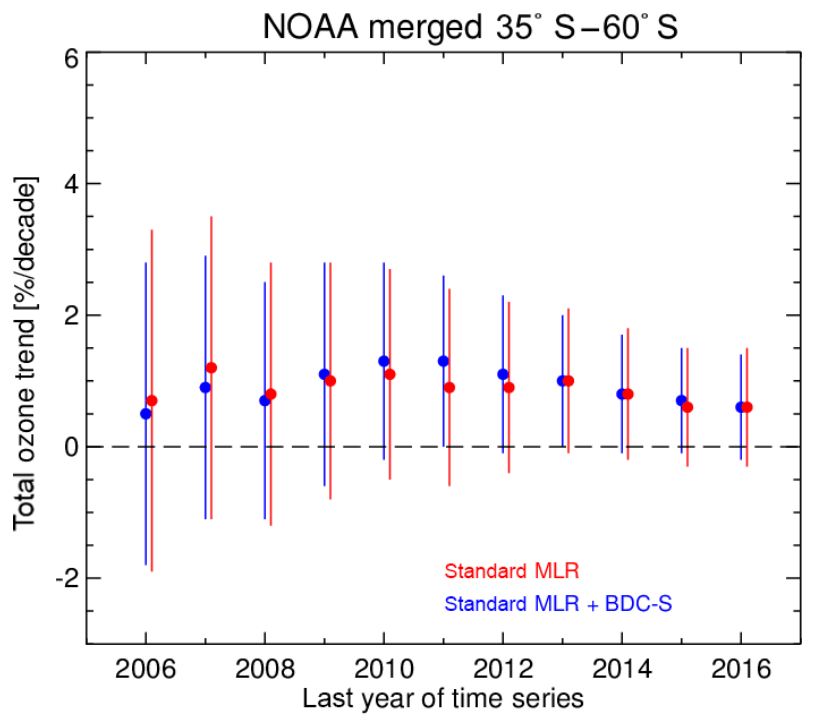

Figure 5. Same as Fig. 4 but for $\mathrm{SH}$ extratropics $\left(35^{\circ} \mathrm{S}-60^{\circ} \mathrm{S}\right)$.

Fig. 2 and Steinbrecht et al., 2011). Despite the reasonable fitting, this high anomaly increased the trend through 2010 to $+1.8 \%$ decade $^{-1}$ which was statistically significant at that time (Fig. 4).

The trend results do not vary much with additional terms used in the MLR. The standard MLR and the extended MLR (adding BDC-N and AO in the NH and BDC-S in the $\mathrm{SH})$ yield about the same trend results, but the latter provides smaller uncertainties because the explained variance increases significantly with the added terms $(\sim 10 \%$ in the $\mathrm{NH}$ ). In the SH extratropics (Fig. 5), the trends did not vary 
much during the last few years, but uncertainties have been reduced to slightly below $1 \%$ decade $^{-1}$.

In the tropics, both GSG and WOUDC show significant trends of $+0.8 \pm 0.4$ and $+0.5 \pm 0.5 \%$ decade $^{-1}$ after 1996, respectively, while all other datasets (NASA, NOAA, GTO) show smaller and insignificant trends (Table 3 and Fig. 6). It appears that for the former datasets, in particular the GSG dataset, some decadal drifts are evident. The difference between the maximum and lowest trends is less than $1 \%$ decade $^{-1}$ which is within the $1-3 \%$ decade $^{-1}$ stability requirement for long-term satellite datasets (OZONE-CCIURD, 2016).

One should keep in mind that significance of trends in some zonal bands and for some datasets that are barely significant at $2 \sigma$ can easily vanish depending on the choice of proxies or set of fitting parameters (Chipperfield et al., 2017). Given the fact that additional uncertainties from the merging of the datasets as well as in the calculation of zonal mean data from sparse ground-based data are not accounted for here, all observed trends are likely not significant yet.

In the last ozone assessment (Pawson et al., 2014), a nearglobal average $\left(60^{\circ} \mathrm{S}-60^{\circ} \mathrm{N}\right)$ increase of about $+1 \pm 1.7 \%$ from ground and space measurements from 2000 to 2013 (corresponding roughly to a $0.8 \% \mathrm{decade}^{-1}$ increase) was reported. For the extended period considered here (19972016), the trends appear much smaller (near-zero trends in the tropics and $\mathrm{NH}$, except for two datasets in the tropics). Only in the SH the trends are about $0.6 \pm 0.6 \%$ decade $^{-1}$ for most datasets (see Table 3 ). In the extratropics, trends (Figs. 4 and 5) were reduced by about half by extending the time series from 2013 to 2016, although this difference is within the trend uncertainties. It is evident from the time series (Figs. 2 and 3) that most of the added years since 2013 show belowaverage ozone compared to the decade before.

The pre-ODS peak trends derived here are in good agreement with the integrated profile trends reported in Tables 2-4 of Pawson et al. (2014). The trends after 1997 reported here are about half of the trends reported by Pawson et al. (2014), as explained above. Nevertheless, within the combined uncertainties, trends agree. Some of the differences may also be due to the different time periods considered (e.g., starting in 2000 versus 1997).

Our results are also largely consistent with more recent profile trend studies (Bourassa et al., 2017; Sofieva et al., 2017; Steinbrecht et al., 2017) that basically show mostly insignificant trends at lower stratosphere altitudes.

\section{Latitude-dependent ozone trends}

In Fig. 7, zonal mean total ozone trends before and after the ODS peak in 1996 are shown for all five datasets as a function of latitude from $60^{\circ} \mathrm{S}$ to $60^{\circ} \mathrm{N}$ in steps of $5^{\circ}$. In order to better compare the results from one dataset to the others, all remaining datasets are overplotted without their uncertain-

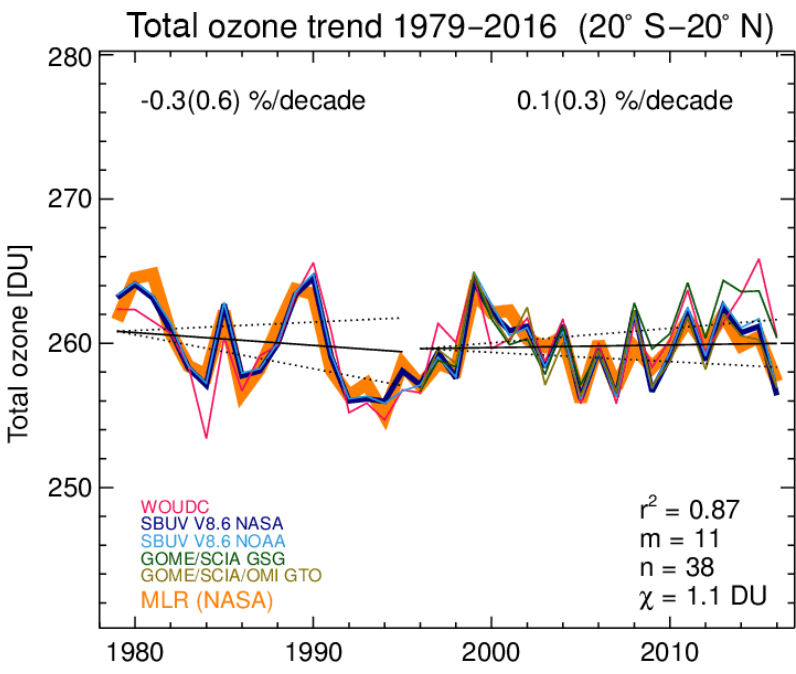

Figure 6. Same as Fig. 2 but for the $20^{\circ} \mathrm{S}-20^{\circ} \mathrm{N}$ zonal band (tropics) and MLR applied to NASA SBUV MOD v8.6. In the tropics, the standard MLR plus BDC-S term was used.

ties. For all datasets, the trends since 1996 are mostly below $1 \%$ decade $^{-1}$ similar to the results obtained in our previous study (Chehade et al., 2014) and what was derived from the broader zonal bands (previous section). For some latitudes, trends are barely statistically significant at $2 \sigma$. Before discussing the trends in more detail, the way the MLR was applied to obtain the trends as well as some other diagnostics will be presented and discussed.

The trends were calculated using the full MLR. The regression at each latitude band was repeated by removing those terms in the extended regression (Eq. 4) for which the corresponding fit coefficient was smaller than its $2 \sigma$ uncertainty. Figure 8 shows the square correlation between the regression model and observation and $\chi$ values as a function of latitude for the NASA and NOAA regressions. The square correlation varies between 0.7 and 0.9 for the full regression. The results for the NASA fit using the standard regression are also shown, demonstrating that adding the BDC-S term improves the fits at the $\mathrm{SH}$ middle latitudes and $\mathrm{NH}$ tropics (higher $r^{2}$ and lower $\chi$ ), while BDC-N and AO improve at $\mathrm{NH}$ middle latitudes. In the SH low latitudes, the standard model was sufficient (no additional terms needed). The importance of the BDC-S term in the NH tropics is for the first time reported and will be discussed later.

An important question arises as to how sensitive the trends are, in particular the ones after 1996, to additional terms from Eq. (4) in the regression. As an example, the trend results for the NOAA data using the standard model and the full MLR are displayed in Fig. 9. The post-ODS peak trends are nearly unchanged, indicating that the recent trends are not sensitive to the additional terms used, which is the case for all datasets; however, the full MLR reduces the trend uncertainty. Within the uncertainties, the pre-1996 trends are also 


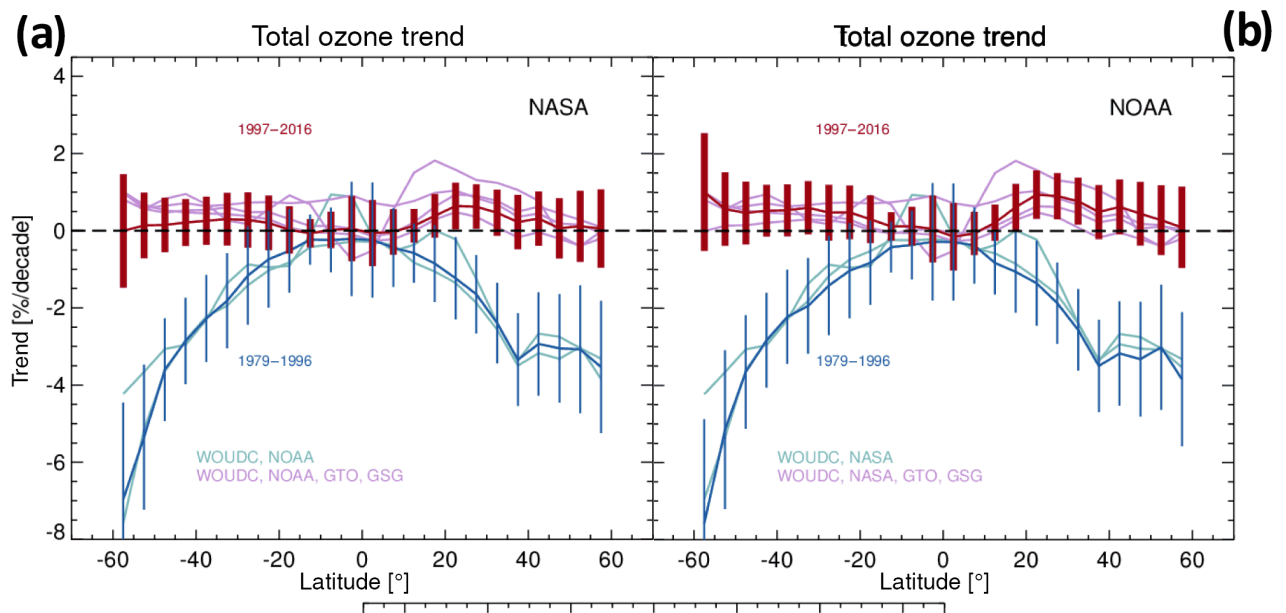

(c)
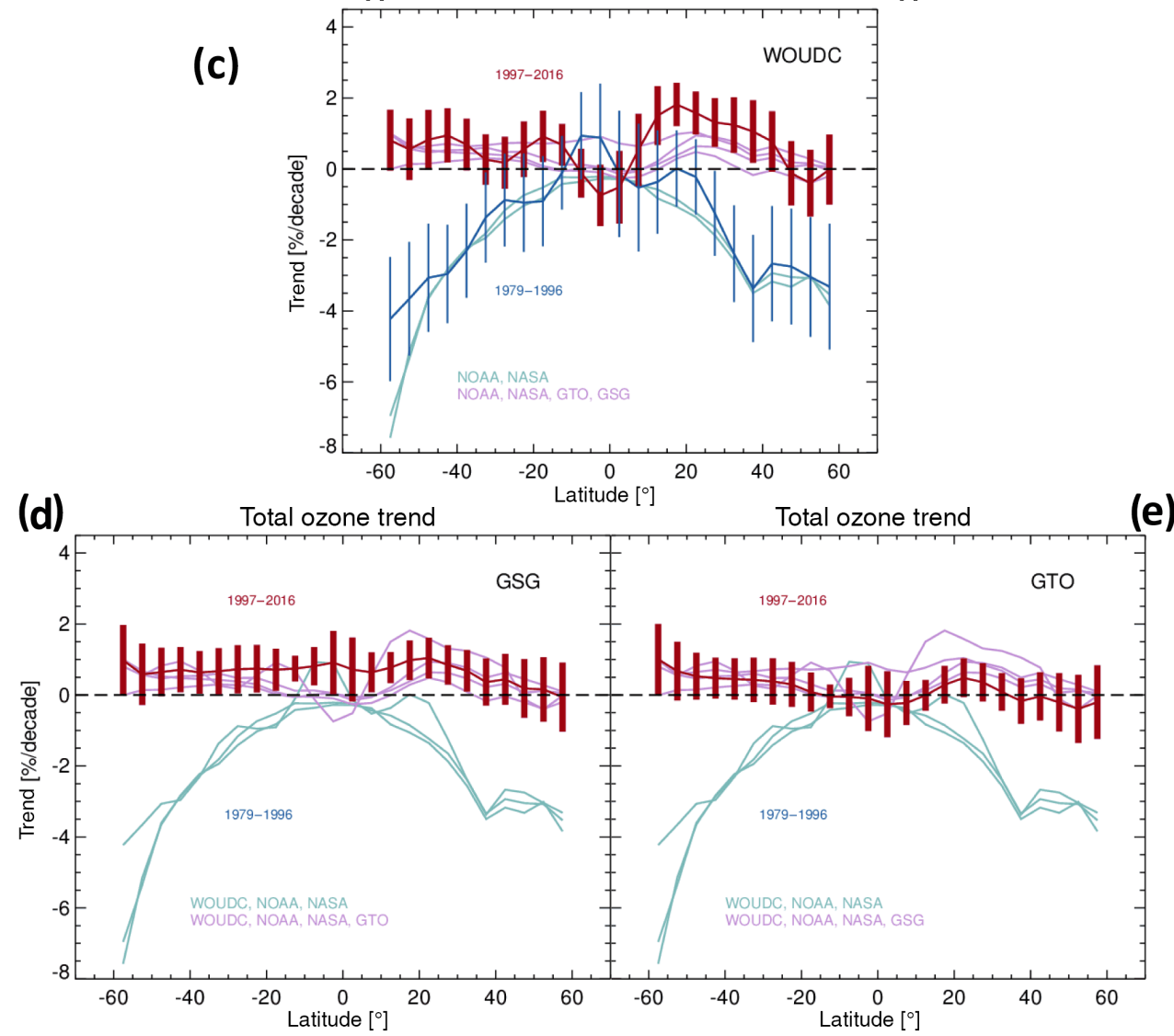

Figure 7. Linear trends and in $\%$ decade $^{-1}$ and $2 \sigma$ uncertainty bars before (red) and after (blue) year 1996. (a) NASA SBUV, (b) NOAA SBUV, (c) WOUDC, (d) GSG, and (e) GTO. Trends were calculated in $5^{\circ}$ zonal bins from $60^{\circ} \mathrm{S}$ to $60^{\circ} \mathrm{N}$ using the full regression model. In panels (d) and (e), the trends before the pre-ODS peak are not shown as the GSG and GTO are mainly available after 1995. In light colors (red and blue), trends from all datasets are overlaid in each panel to facilitate comparison.

identical in the standard and full MLRs. At the NH middle latitudes, the addition of the BDC-N and AO terms reduces the downward trend until 1996 by about $1 \%$ decade $^{-1}$. As all proxies were not detrended, the AO and BDC-N terms also contribute to the long-term trends (thus reducing the remaining linear trends). Apart from the year-to-year variability, the AO index increased throughout the 1980s along with the EESC (ODSs) as shown in Fig. 1 in Weber et al. (2011) (see also Zhang et al., 2017). The very high total ozone observed at NH middle latitudes in 2010 (Fig. 2) was linked to extreme negative AO (Steinbrecht et al., 2011) as well as a very strong NH BDC (Weber et al., 2011) during Arctic winter in the same year. 


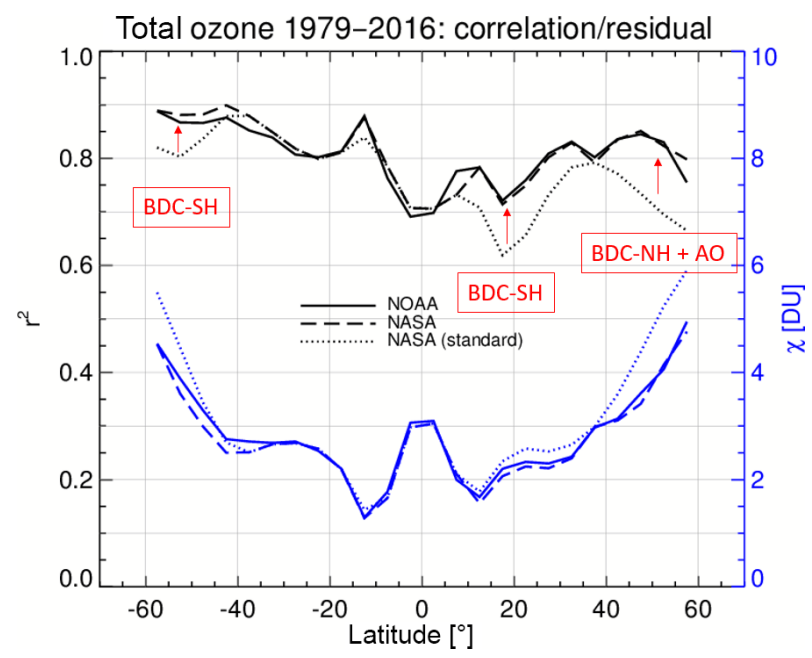

Figure 8. Correlation $\left(r^{2}\right)$ between observed time series and regression (black) and MLR residual ( $\chi$, blue) as a function of latitude. Results are shown for NASA and NOAA data using the full regression as well as results from standard MLR (NASA only). See caption for Fig. 2 for the definition of $\chi$. Improvement in the regression is evident from adding BDC-S at $\mathrm{SH}$ middle latitudes and $\mathrm{NH}$ subtropics and by adding BDC-N and $\mathrm{AO}$ terms (NH middle latitudes) to the standard regression as indicated by the red arrows.

The contribution of the various factors (solar cycle, QBO, ENSO, aerosol, and so on) to ozone variability as a function of latitude is shown in Fig. 10 for two of the datasets (NASA, WOUDC). Plotted are the signed maximum responses in Dobson units (DU), which are the differences between the maximum and minimum values of the regression term time series. A negative sign means that the ozone response is anticorrelated with the proxy change. The ozone response to the factors are in very good agreement with our previous results from Chehade et al. (2014) based on data up to 2012. The maximum solar response of about 4-6DU in the tropics is in agreement with the $\sim 2 \%$ change from solar minimum to maximum in the lower stratosphere reported by Soukharev and Hood (2006). Solar ozone responses are significant at all latitudes and are the result of the solar impact on atmospheric dynamics (Gray et al., 2010).

In the inner tropics, the ozone response to the QBO terms changes sign poleward of $10-15^{\circ}$ latitudes in each hemisphere, which means positive ozone changes in the inner tropics are observed in years dominated by the QBO west phase. A new result is that the BDC-S has a significant contribution at low NH latitudes. At middle latitudes above about $40^{\circ}$, ozone increases are associated with high absolute eddy heat fluxes (BDC proxy) as expected from the enhanced downwelling related to a stronger residual circulation. The opposite effect is seen at low latitudes (ascending branch of the BDC) with lower ozone due to enhanced upwelling and horizontal divergence (Randel et al., 2002; Weber et al., 2011). Indeed, the BDC-S ozone response has op-

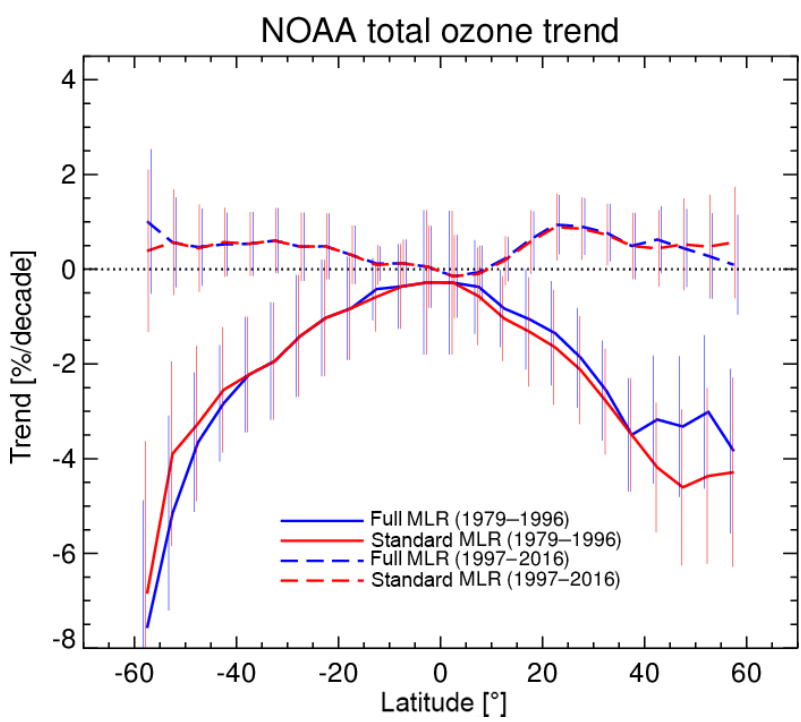

Figure 9. Linear trends in $\%$ decade $^{-1}$ before and after 1996 by applying the standard (red) and extended MLR (blue) to NOAA data. Uncertainties are given as $2 \sigma$. Dashed lines are the trends after 1996 and solid lines before 1996.

posite signs between the low and high latitudes. The extension of the BDC-S response into NH low latitudes may be a result of the upper branch of the SH meridional circulation extending into the NH (Andrews et al., 1987). It is somewhat surprising that a similar tropical response is not evident in the $\mathrm{NH}$. However, the QBO indices have a significant correlation with the BDC-N proxy $(r \sim-0.7)$. The lower stratospheric QBO in the west phase (positive QBO index) allows planetary waves to be more strongly deflected towards the Equator, thus reducing the perturbation of the westerly flow in the extratropical stratosphere (Baldwin et al., 2001), resulting in a weakening of the meridional winter BDC, lower middle latitude eddy heat flux, and reduced high latitude ozone due to reduced downwelling and higher ozone losses due to lower polar stratospheric temperatures (e.g., Weber et al., 2011).

The aerosol effect due to the Mt. Pinatubo eruption in 1991 has the largest effect on ozone at high northern latitudes with a reduction of up to 20DU (NASA) to 25 DU (WOUDC) in 1993. Significant ozone depletion was also observed in the $\mathrm{NH}$ following the El Chichón major volcanic eruption in 1982 (e.g., Hofmann and Solomon, 1989). A positive ozone response to the El Chichón is evident in the SH middle latitudes, most likely due to the specific circulation changes induced by this volcanic event (Schnadt Poberaj et al., 2011; Aquila et al., 2013; Dhomse et al., 2015). This is also believed to have caused an initial extratropical increase in $\mathrm{SH}$ extratropical total ozone during the first 6 months following the Pinatubo eruption.

Similar to the results from the broad zonal band trends, Fig. 7 shows that the latitude-dependent post-ODS peak trends (Fig. 7) are generally smaller than the trends reported 
(a) NASA total ozone 1979-2016

(b) WOUDC total ozone 1979-2016

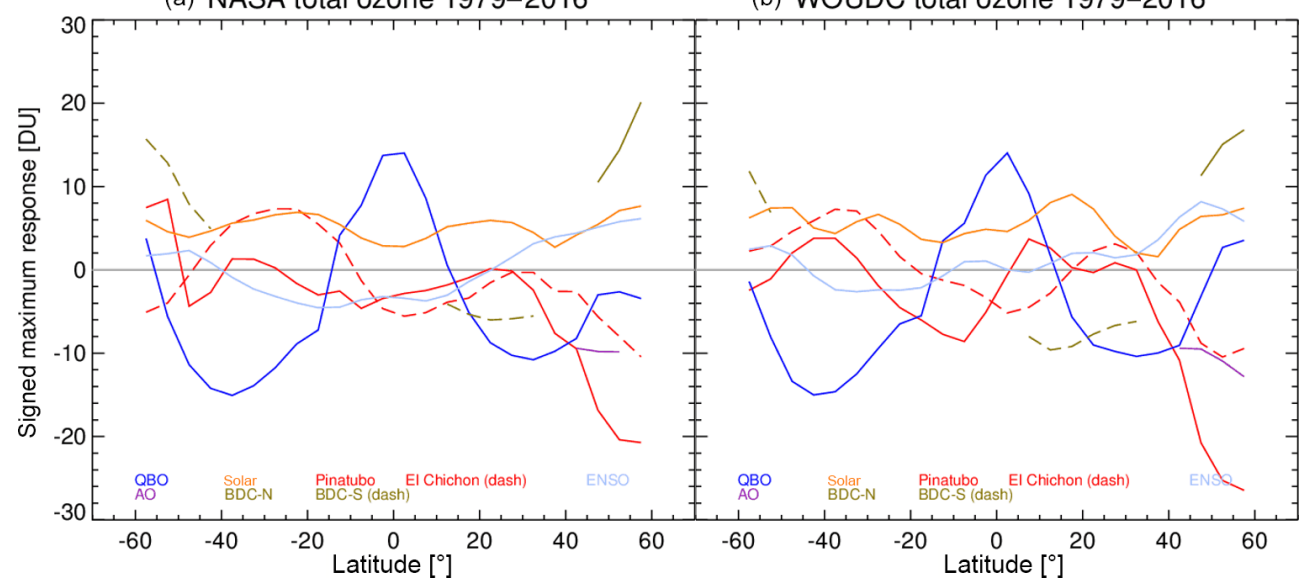

Figure 10. Signed maximum response during the period 1979-2016 from various factors (terms) in the MLR. (a) NASA data; (b) WOUDC data. Negative values mean that total ozone is anticorrelated with the corresponding proxy (factor). Maximum response is the difference between the maximum and minimum values of the regression term in the MLR time series. Note that, in the MLR regression, negative values of the BDC-S proxy are used, meaning that positive values correspond to enhanced BDC driving in both hemispheres.

Table 4. The 2000-2016 polar total ozone trends in March (NH), September (SH), and October (SH). Uncertainties are provided for $2 \sigma$ and trends in bold indicate statistical significance. $r^{2}$ is the squared Pearson correlation and $\chi$ the residual (see caption of Table 3). The results were obtained from the standard MLR with the respective hemispheric BDC term added.

\begin{tabular}{|c|c|c|c|c|c|c|c|}
\hline Zonal bands & MLR & & NASA & NOAA & GSG & GTO & WOUDC \\
\hline $60-90^{\circ} \mathrm{N}$ & standard + BDC-N & $\begin{array}{l}\text { trend } \geq 2000 \\
\left(\% \text { decade }^{-1}\right)\end{array}$ & +0.4 (37) & $+1.2(37)$ & $+0.9(39)$ & $+0.5(37)$ & $+0.4(45)$ \\
\hline \multirow[t]{3}{*}{ March } & & $\begin{array}{l}\text { trend }<2000 \\
\left(\% \text { decade }^{-1}\right)\end{array}$ & $-2.0(63)$ & $-3.4(64)$ & - & - & $-2.8(75)$ \\
\hline & & $r^{2}$ & 0.80 & 0.81 & 0.80 & 0.80 & 0.70 \\
\hline & & $\chi(\mathrm{DU})$ & 14.2 & 14.5 & 15.2 & 14.2 & 17.7 \\
\hline $60-90^{\circ} \mathrm{S}$ & standard + BDC-S & $\begin{array}{l}\text { trend } \geq 2000 \\
\left(\% \mathrm{decade}^{-1}\right)\end{array}$ & +10.1 (69) & $+8.1(73)$ & $+8.2(62)$ & $+9.1(56)$ & $+8.6(68)$ \\
\hline \multirow[t]{3}{*}{ September } & & $\begin{array}{l}\text { trend }<2000 \\
\left(\% \text { decade }^{-1}\right)\end{array}$ & $-12.2(107)$ & $-13.9(114)$ & - & - & $-19.3(106)$ \\
\hline & & $r^{2}$ & 0.82 & 0.85 & 0.90 & 0.90 & 0.88 \\
\hline & & $\chi(\mathrm{DU})$ & 14.1 & 15.0 & 12.8 & 12.0 & 14.0 \\
\hline $60-90^{\circ} \mathrm{S}$ & standard + BDC-S & $\begin{array}{l}\text { trend } \geq 2000 \\
\left(\% \text { decade }^{-1}\right)\end{array}$ & $+0.9(77)$ & $+2.1(71)$ & $2.7(76)$ & $+2.7(79)$ & $+5.7(102)$ \\
\hline \multirow[t]{3}{*}{ October } & & $\begin{array}{l}\text { trend }<2000 \\
\left(\% \text { decade }^{-1}\right)\end{array}$ & $-18.0(122)$ & $-18.1(112)$ & - & - & $-12.7(161)$ \\
\hline & & $r^{2}$ & 0.82 & 0.84 & 0.81 & 0.81 & 0.75 \\
\hline & & $\chi(\mathrm{DU})$ & 16.8 & 15.5 & 16.6 & 17.2 & 22.3 \\
\hline
\end{tabular}

Bold numbers indicate statistical significance at $2 \sigma$.

in the last WMO/UNEP ozone assessment (Pawson et al., 2014) which varied between +1 and $+2 \%$ decade $^{-1}$. The $\mathrm{NH}$ extratropical trends are below $+0.5 \%$ decade $^{-1}$ and statistically insignificant. In the $\mathrm{SH}$, trends can reach up to $+0.7 \%$ decade $^{-1}$ and at some latitudes barely reach the $2 \sigma$ uncertainty level, except for the NASA dataset.

Largest variations in trends between the datasets are seen in the tropics. Here, both SBUV datasets show basically zero trends, the WOUDC and GTO negative trends in the inner tropics, and GSG statistically significant positive trends that are near $10^{\circ}$ latitudes reaching about $+0.8 \%$ decade $^{-1}$. Near the same latitudes, WOUDC trends are also positive and statistically significant. One large issue is that the ground-based data are quite sparse in the tropics, particularly at SH latitudes, and generally towards the end of the data record as many stations have not yet submitted updates to the database. 

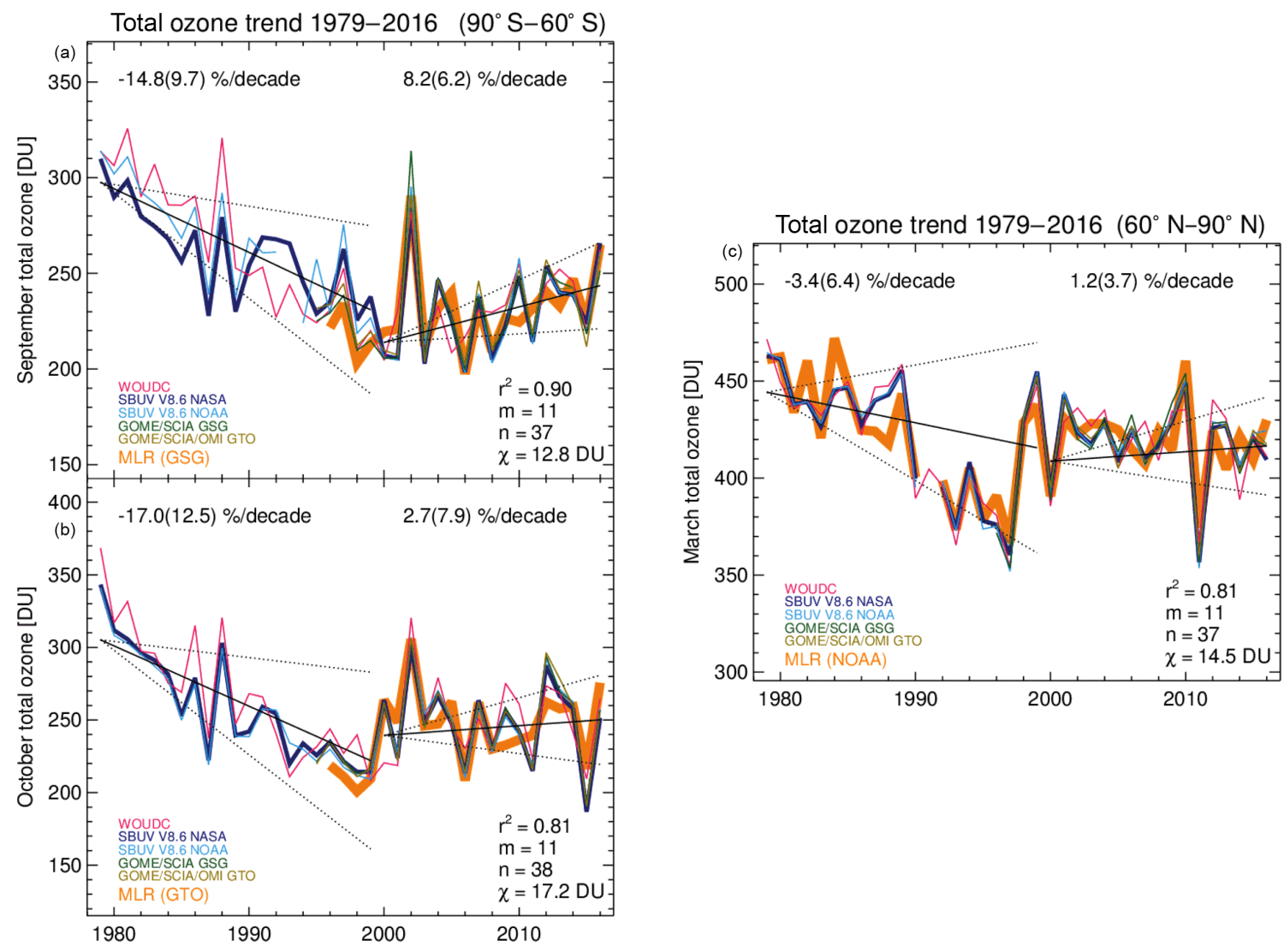

Figure 11. Total ozone time series for the SH and NH polar cap $\left(60-90^{\circ}\right)$ and MLR time series (orange line) applied to one of the datasets. (a) SH September and MLR applied to GSG; (b) October and MLR applied to GTO; (c) NH March and MLR applied to NOAA. MLR results are shown for the standard regression plus respective hemispheric BDC term.

An interesting result is that $\mathrm{NH}$ subtropical trends (20$30^{\circ} \mathrm{N}$ ) peak at about $+1 \%$ decade $^{-1}$ and are significant, with the exception of those in the GTO dataset, which are at the lower end of the range observed. The subtropics are regions where total ozone shows quite large gradients in the transition from the tropics (lower ozone) to the extratropics (higher ozone). A shift of the subtropical transport barrier into the tropical region could increase ozone at subtropical latitudes. Indeed, a southward shift of about $5^{\circ}$ of the tropical belt below $30 \mathrm{~km}$ altitude has been inferred from lower stratospheric ozone trends (Stiller et al., 2012; Eckert et al., 2014). A recent study by Haenel et al. (2015) indicates that lower stratospheric age of air in the NH subtropics and extratropics has been increasing in recent years (subtropical air becoming more extratropical and reduced BDC in $\mathrm{NH}$ ), while in the SH subtropics age of air has variable trends in the lower stratosphere that can be negative and positive depending on altitude and is largely negative in the SH extratropics. The latter would mean that the BDC is getting stronger in the SH, which would result in larger SH extratropical lower stratospheric ozone trends as compared to the NH. However, the recent stratospheric ozone profile trend studies do not indicate such a hemispheric trend asymmetry in the lower stratosphere (Bourassa et al., 2017; Steinbrecht et al., 2017; Sofieva et al., 2017).

\section{Trends in polar spring}

In a recent study by Solomon et al. (2016), evidence for a significant positive trend in the SH polar region in September was reported. Other studies also indicated some early signs of ozone recovery in Antarctic spring and summer (Salby et al., 2011; Kuttippurath and Nair, 2017). September and October are months when the ozone hole area reaches its maximum and total ozone above Antarctica exhibits minimum values (see https://ozonewatch.gsfc.nasa.gov/meteorology/SH. html). A MLR has been applied to monthly mean polar total ozone for September and October in the SH as well as March in the NH. In the Arctic, substantial polar ozone depletion is sporadically observed when stratospheric winter and spring are sufficiently cold (e.g., Manney et al., 2011; Manney and Lawrence, 2016). For these 3 months, the monthly mean proxies for the respective months were used in the MLR, except for the BDC proxies which were taken as an average from March to September or October in the SH, respectively, 
Table 5. The 1979-1996 and 1997-2016 annual and near-global mean total ozone trends. For further information on variables, see Table 3. Results are from the standard MLR and the full MLR including BDC terms from both hemispheres and the AO term.

\begin{tabular}{|c|c|c|c|c|c|c|c|}
\hline Zonal bands & MLR & & NASA & NOAA & GSG & GTO & WOUDC \\
\hline$-60^{\circ} \mathrm{S}-60^{\circ} \mathrm{N}$ & full & trend $>1996\left(\%\right.$ decade $\left.^{-1}\right)$ & $+0.2(3)$ & $+0.5(4)$ & $+0.7(3)$ & $+0.2(3)$ & $+0.6(3)$ \\
\hline \multirow{3}{*}{ Annual } & & trend $\leq 1996\left(\%\right.$ decade $\left.^{-1}\right)$ & $-1.8(7)$ & $-2.0(7)$ & - & - & $-1.2(6)$ \\
\hline & & $r^{2}-r+2$ & 0.92 & 0.92 & 0.94 & 0.94 & 0.92 \\
\hline & & $\chi(\mathrm{DU})$ & 1.3 & 1.3 & 1.2 & 1.2 & 1.2 \\
\hline$-60^{\circ} \mathrm{S}-60^{\circ} \mathrm{N}$ & standard & trend $>1996\left(\%\right.$ decade $\left.^{-1}\right)$ & $+0.2(3)$ & $+0.5(3)$ & $+0.7(3)$ & $+0.2(3)$ & $+0.6(4)$ \\
\hline \multirow[t]{3}{*}{ Annual } & & trend $\leq 1996\left(\%\right.$ decade $\left.^{-1}\right)$ & $-2.1(7)$ & $-2.3(7)$ & - & - & $-1.7(6)$ \\
\hline & & $r^{2}-r-1$ & 0.90 & 0.91 & 0.91 & 0.93 & 0.86 \\
\hline & & $\chi(\mathrm{DU})$ & 1.3 & 1.4 & 1.3 & 1.2 & 1.4 \\
\hline
\end{tabular}

Bold numbers indicate statistical significance at $2 \sigma$.

and from September to March in the NH. We use the year 2000 as a start for the post-ODS peak trends (Newman et al., 2006). The regression results are summarized in Table 4 and MLR time series are shown for each of the months for one of the total ozone datasets in Fig. 11.

In SH September, the post-ODS peak trends of the various datasets vary between +8 and $+10 \%$ decade $^{-1}$ with a $2 \sigma$ uncertainty of about $7 \%$ decade $^{-1}$. The Antarctic September trend is barely significant at the $2 \sigma$ level and confirms the findings of Solomon et al. (2016). Changes in the regression model, use of different proxies, and considerations of inherent drift uncertainties can easily remove the significance (de Laat et al., 2015; Chipperfield et al., 2017). In contrast, the October trends are much smaller (about $3 \%$ decade $^{-1}$ ) and statistically insignificant, which is also in agreement with Solomon et al. (2016).

Solomon et al. (2016) and Ivy et al. (2017) showed from chemistry-climate model simulations that the Calbuco volcanic event substantially contributed to the observed polar ozone loss in 2015. Even though we used the aerosol data from Mills et al. (2016), as used by Solomon et al. (2016) and Ivy et al. (2017) as input to their climate model, as a proxy in our regression, the impact of the aerosol term was found to be negligible in 2015. The apparent contradiction of the aerosol impact on Antarctic ozone between Solomon and Ivy et al. and our study should not be overstated. The fitting of the aerosol proxy data based on Mills et al. is dominated by the Pinatubo event and may therefore not be properly scaled during the Calbuco volcanic event. It is difficult to isolate minor volcanic events with stratospheric impact in the MLR using separate aerosol proxy terms as is done for the larger El Chichón and Pinatubo events. This is clearly a limitation of the MLR approach.

In the Arctic, March total ozone trends are quite small (below $1 \%$ decade $^{-1}$ ) and insignificant, similar to the trends observed in NH middle latitude annual means, albeit with much larger uncertainties (on the order of $4 \%$ decade $^{-1}$ at $2 \sigma$ ). Also, the pre-ODS peak trends in the Arctic (about $-3 \%$ decade $^{-1}$ ) are similar to the annual mean trends ob- served in the extratropics $\left(30-60^{\circ} \mathrm{N}\right)$. At first sight, it seems surprising, as in the 1990s and selected years after 2000 there was substantial polar ozone depletion. As the polar ozone losses occur mostly in cold Arctic winters that are usually associated with years of very low BDC driving, it seems that the BDC term in the MLR accounted for the polar chemical losses. The remaining trends are in excellent agreement with the "gas-phase" chemistry trends at middle latitudes (before and after the ODS peak). In the SH, the polar ozone losses are much larger and the "linear" scaling of polar losses with the BDC proxy is not fully given so that the Antarctic trends are larger, or, in other words, the linear trends may have nonnegligible contributions from polar ozone losses.

\section{Summary and conclusions}

Updated trends were derived from five different merged total ozone datasets that have been extended up to the year 2016. A MLR with ILTs before and after the maximum stratospheric halogen content $(\sim 1996)$ was applied to annual means in broad zonal bands as well as narrow $5^{\circ}$ latitude bands up to $60^{\circ}$ latitudes. In most cases, the results from the last ozone assessment (Pawson et al., 2014) and from other studies (Chehade et al., 2014; Zvyagintsev et al., 2015, and earlier studies) confirmed that total ozone has been stable since about 1996, which is a significant change from the earlier decline observed globally outside the tropics. Globally, the post-ODS peak trends vary generally between near-zero trends (NH extratropics) and positive trends of $+0.7 \%$ decade $^{-1}$ (SH extratropics) with a statistical trend uncertainty of about $0.7 \%$ decade $^{-1}(2 \sigma)$ after 20 years of observations. We may therefore conclude that we are about to emerge into the phase of ozone recovery as is also shown by chemistry-climate and chemistry-transport models (e.g., Eyring et al., 2010; Shepherd et al., 2014; Solomon et al., 2016; Chipperfield et al., 2017). Both the regression applied to datasets (e.g., in our study) and models capture the dynamical variability well and their results are consistent. 


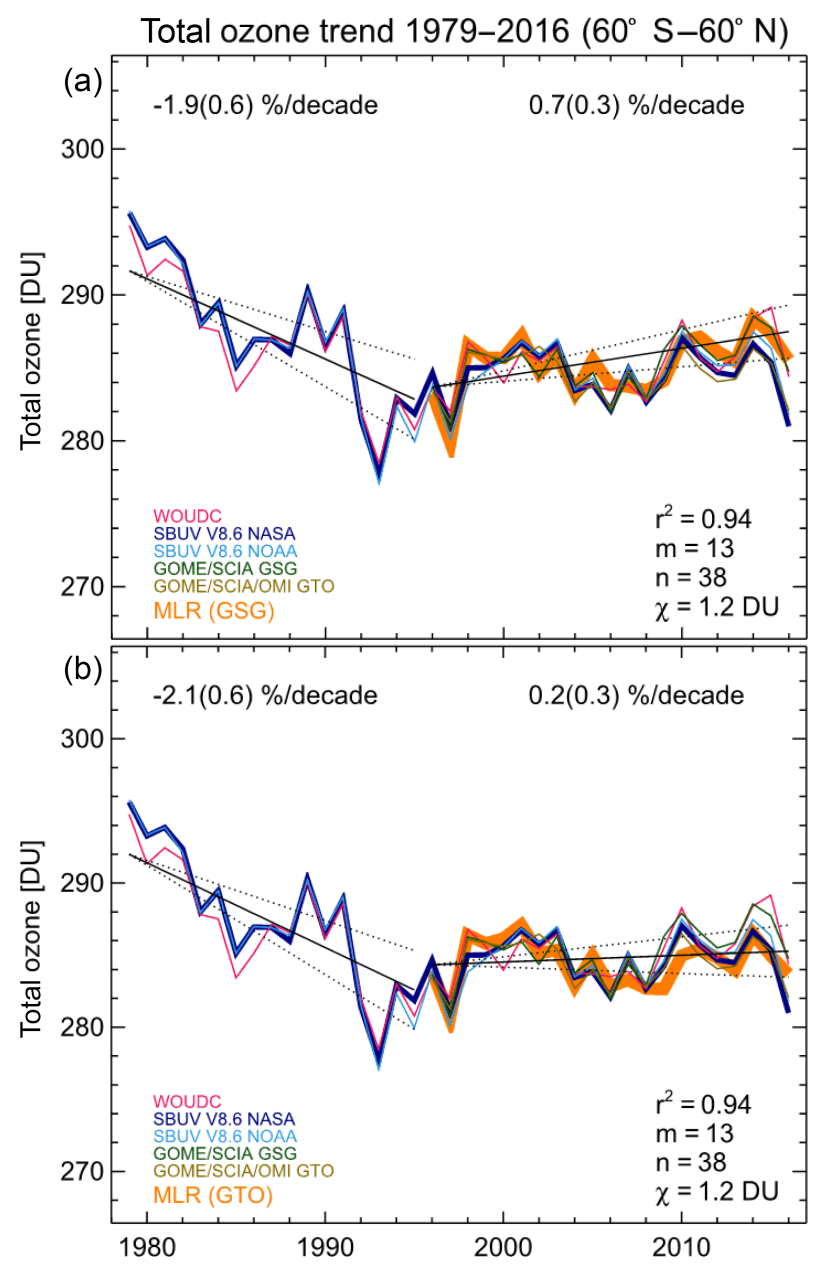

Figure 12. Near-global total ozone time series $\left(60^{\circ} \mathrm{S}-60^{\circ} \mathrm{N}\right)$ and MLR time series (orange line) applied to GSG (a) and GTO (b). Full MLR was applied including both BDC terms and AO.

All post-ODS peak trends are about half of the trends reported in Pawson et al. (2014) but the changes are still within the trend uncertainties. The main reason is that in most regions total ozone in recent years showed annual means that were lower than the recent decadal mean but were well within the variability that was observed during the last 20 years.

In some regions, some of the datasets show significant positive trends. In the tropical band $\left(<20^{\circ}\right)$, recent trends are significant for two (GSG, WOUDC) and in the SH (35$60^{\circ} \mathrm{S}$ ) for three (GSG, GTO, WOUDC) out of five datasets (Table 3). The significance of these trend estimates is close to $2 \sigma$. The uncertainties reported here are purely statistical and do not account for uncertainties that may arise from the merging of the individual satellites (Frith et al., 2014, 2017) as well as from sparse sampling of ground-based data affecting the zonal mean estimates. Also, the significance of trends may get altered (or become insignificant) depending on the explicit choice of regression setup (e.g., which terms to add) as well as choice of proxies for a given process.
The latitude-dependent trends (Fig. 7) after 1996 are largely consistent with the results from the broader zonal bands. A striking feature is that most datasets see larger positive and statistically significant trends at subtropical latitudes between 20 and $30^{\circ} \mathrm{N}$. A southward shift of the tropical belt (e.g., Eckert et al., 2014) could be a potential explanation; however, a recent study shows that a markedly positive trend is not observed in most ozone profile datasets (Steinbrecht et al., 2017).

The higher trends at $\mathrm{NH}$ subtropics have some impact on the near-global trends $\left(60^{\circ} \mathrm{S}-60^{\circ} \mathrm{N}\right)$ derived from our MLR analyses as summarized in Table 5 and Fig. 12. Three out of the five datasets (NOAA, GSG, and WOUDC) show statistically significant trends of about $+0.6 \pm 0.3 \%$ decade $^{-1}$ on average. This trend is smaller than the trend derived from profile data for the period 2000 to $2013(+1.1 \pm$ $1.7 \%$ decade $^{-1}$ ) reported in Tables 2-4 of Pawson et al. (2014) which was derived from the combination of ozone profile data. Figure 12 shows the MLR results of data having the lowest (GTO) and highest post-ODS peak trends (GSG). One should keep in mind that from MLR analyses alone we can not uniquely attribute the observed trends, as they may have a significant contribution from climate change and possible feedback on atmospheric dynamics and chemistry that are difficult to disentangle without the use of chemistryclimate models.

The observed positive trends above Antarctica in September since 2000 as reported by Solomon et al. (2016) were confirmed by our MLR analysis; however, the impact from aersols from the recent series of minor volcanic eruptions was found to be minor in contrast to the results from Solomon et al. (2016) and Ivy et al. (2017). In October, the MLR trends above Antarctica were much smaller and statistically not different from zero as were trends from the Arctic in March for all five datasets.

Adding 4 years of data in the various long-term total ozone data records has now further reduced the statistical uncertainties in the zonal mean trends to below $1 \%$ decade $^{-1}$. We consider the uncertainties cited here as lower limits, as we do not account for added uncertainties from the drifts in and from merging the data, the latter needed to obtain long-term datasets, and the data sampling was low (mainly groundbased data).

Continued ozone observations and monitoring are needed to consolidate the evidence of ozone recovery and also further improve our understanding of the complex ozoneclimate feedback (in combination with chemistry-climate modeling) that will have a significant impact on future evolution of ozone (Fleming et al., 2011; Zubov et al., 2013; Pawson et al., 2014).

Data availability. The sources of the various datasets and proxy time series (explanatory variables) used in this study are summarized in Tables 1 and 2. 
Competing interests. The authors declare that they have no conflict of interest.

Special issue statement. This article is part of the special issue "Quadrennial Ozone Symposium 2016 - Status and trends of atmospheric ozone (ACP/AMT inter-journal SI)". It is a result of the Quadrennial Ozone Symposium 2016, Edinburgh, United Kingdom, 4-9 September 2016.

Acknowledgements. Melanie Coldewey-Egbers and Diego Loyola are grateful for the support by the ESA Climate Change Initiative project ozone_cci. Mark Weber and John P. Burrows acknowledge the financial support of the DFG Research Unit SHARP (Stratospheric Change and its Role for Climate Prediction) and the state of Bremen. Stacey M. Frith is supported by the NASA Long Term Measurement of Ozone program WBS 479717. We are grateful for the very helpful comments by both reviewers.

The article processing charges for this open-access publication were covered by the University of Bremen.

Edited by: Stefan Reis

Reviewed by: two anonymous referees

\section{References}

Anderson, J., Russell, J. M., Solomon, S., and Deaver, L. E.: Halogen Occultation Experiment confirmation of stratospheric chlorine decreases in accordance with the Montreal Protocol, J. Geophys. Res.-Atmos., 105, 4483-4490, https://doi.org/10.1029/1999JD901075, 2000.

Andrews, D. G., Holton, J. R., and Leovy, C. B.: Middle Atmosphere Dynamics, Academic Press, San Diego, 1987.

Aquila, V., Oman, L. D., Stolarski, R., Douglass, A. R., and Newman, P. A.: The response of ozone and nitrogen dioxide to the eruption of Mt. Pinatubo at southern and northern midlatitudes, J. Atmos. Sci., 70, 894-900, https://doi.org/10.1175/JAS-D-120143.1, 2013.

Baldwin, M. P., Gray, L. J., Dunkerton, T. J., Hamilton, K., Haynes, P. H., Randel, W. J., Holton, J. R., Alexander, M. J., Hirota, I., Horinouchi, T., Jones, D. B. A., Kinnersley, J. S., Marquardt, C., Sato, K., and Takahashi, M.: The Quasi-Biennial Oscillation, Rev. Geophys., 39, 179-229, https://doi.org/10.1029/1999RG000073, 2001.

Bhartia, P. K., McPeters, R. D., Flynn, L. E., Taylor, S., Kramarova, N. A., Frith, S., Fisher, B., and DeLand, M.: Solar Backscatter UV (SBUV) total ozone and profile algorithm, Atmos. Meas. Tech., 6, 2533-2548, https://doi.org/10.5194/amt-6-2533-2013, 2013.

Bourassa, A. E., Degenstein, D. A., Randel, W. J., Zawodny, J. M., Kyrölä, E., McLinden, C. A., Sioris, C. E., and Roth, C. Z.: Trends in stratospheric ozone derived from merged SAGE II and Odin-OSIRIS satellite observations, Atmos. Chem. Phys., 14, 6983-6994, https://doi.org/10.5194/acp-14-6983-2014, 2014.

Bourassa, A. E., Roth, C. Z., Zawada, D. J., Rieger, L. A., McLinden, C. A., and Degenstein, D. A.: Drift-corrected Odin-OSIRIS ozone product: algorithm and updated stratospheric ozone trends, Atmos. Meas. Tech., 11, 489-498, https://doi.org/10.5194/amt11-489-2018, 2018.

Burrows, J. P., Weber, M., Buchwitz, M., Rozanov, V., Ladstätter-Weißenmayer, A., Richter, A., DeBeek, R., Hoogen, R., Bramstedt, K., Eichmann, K.-U., Eisinger, M., and Perner, D.: The Global Ozone Monitoring Experiment (GOME): Mission Concept and First Scientific Results, J. Atmos. Sci., 56, 151-175, https://doi.org/10.1175/15200469(1999)056<0151:TGOMEG>2.0.CO;2, 1999.

Chehade, W., Weber, M., and Burrows, J. P.: Total ozone trends and variability during 1979-2012 from merged data sets of various satellites, Atmos. Chem. Phys., 14, 7059-7074, https://doi.org/10.5194/acp-14-7059-2014, 2014.

Chiou, E. W., Bhartia, P. K., McPeters, R. D., Loyola, D. G., Coldewey-Egbers, M., Fioletov, V. E., Van Roozendael, M., Spurr, R., Lerot, C., and Frith, S. M.: Comparison of profile total ozone from SBUV (v8.6) with GOME-type and ground-based total ozone for a 16-year period (1996 to 2011), Atmos. Meas. Tech., 7, 1681-1692, https://doi.org/10.5194/amt-7-1681-2014, 2014.

Chipperfield, M., Bekki, S., Dhomse, S., Harris, N., Hassler, B., Hossaini, R., Steinbrecht, W., Thiéblemont, R., and Weber, M.: Detecting recovery of the stratospheric ozone layer, Nature, 549, 211-218, https://doi.org/10.1038/nature23681, 2017.

Chubachi, S.: Preliminary results of ozone observations at Syowa Station from February 1982 to January 1983, in: Proc. Sixth Symposium on Polar Meteorology and Glaciology, edited by: Kusunoki, K., vol. 34 of Mem. National Institute of Polar Research Special Issue, 13-19, 1984.

Coldewey-Egbers, M., Weber, M., Lamsal, L. N., de Beek, R., Buchwitz, M., and Burrows, J. P.: Total ozone retrieval from GOME UV spectral data using the weighting function DOAS approach, Atmos. Chem. Phys., 5, 1015-1025, https://doi.org/10.5194/acp-5-1015-2005, 2005.

Coldewey-Egbers, M., Loyola, D. G., Koukouli, M., Balis, D., Lambert, J.-C., Verhoelst, T., Granville, J., van Roozendael, M., Lerot, C., Spurr, R., Frith, S. M., and Zehner, C.: The GOMEtype Total Ozone Essential Climate Variable (GTO-ECV) data record from the ESA Climate Change Initiative, Atmos. Meas. Tech., 8, 3923-3940, https://doi.org/10.5194/amt-8-3923-2015, 2015.

Dee, D. P., Uppala, S. M., Simmons, A. J., Berrisford, P., Poli, P., Kobayashi, S., Andrae, U., Balmaseda, M. A., Balsamo, G., Bauer, P., Bechtold, P., Beljaars, A. C. M., van de Berg, L., Bidlot, J., Bormann, N., Delsol, C., Dragani, R., Fuentes, M., Geer, A. J., Haimberger, L., Healy, S. B., Hersbach, H., Hólm, E. V., Isaksen, L., Kållberg, P., Köhler, M., Matricardi, M., McNally, A. P., Monge-Sanz, B. M., Morcrette, J.-J., Park, B.-K., Peubey, C., de Rosnay, P., Tavolato, C., Thépaut, J.-N., and Vitart, F.: The ERA-Interim reanalysis: configuration and performance of the data assimilation system, Q. J. Roy. Meteor. Soc., 137, 553-597, https://doi.org/10.1002/qj.828, 2011.

de Laat, A. T. J., van der A, R. J., and van Weele, M.: Tracing the second stage of ozone recovery in the Antarctic ozone-hole with a "big data" approach to multivariate regressions, Atmos. Chem. Phys., 15, 79-97, https://doi.org/10.5194/acp-15-79-2015, 2015.

DeLand, M. T., Taylor, S. L., Huang, L. K., and Fisher, B. L.: Calibration of the SBUV version 8.6 ozone data product, Atmos. 
Meas. Tech., 5, 2951-2967, https://doi.org/10.5194/amt-5-29512012, 2012.

De Smedt, I., Van Roozendael, M., Stavrakou, T., Müller, J.-F., Lerot, C., Theys, N., Valks, P., Hao, N., and van der A, R.: Improved retrieval of global tropospheric formaldehyde columns from GOME-2/MetOp-A addressing noise reduction and instrumental degradation issues, Atmos. Meas. Tech., 5, 2933-2949, https://doi.org/10.5194/amt-5-2933-2012, 2012.

Dhomse, S., Weber, M., Wohltmann, I., Rex, M., and Burrows, J. P.: On the possible causes of recent increases in northern hemispheric total ozone from a statistical analysis of satellite data from 1979 to 2003, Atmos. Chem. Phys., 6, 1165-1180, https://doi.org/10.5194/acp-6-1165-2006, 2006.

Dhomse, S. S., Chipperfield, M. P., Feng, W., Hossaini, R., Mann, G. W., and Santee, M. L.: Revisiting the hemispheric asymmetry in midlatitude ozone changes following the Mount Pinatubo eruption: A 3-D model study, Geophys. Res. Lett., 42, 30383047, https://doi.org/10.1002/2015GL063052, 2015.

Dobson, G. M. B.: Forty years' research on atmospheric ozone at Oxford: A history, Appl. Optics, 7, 387, https://doi.org/10.1364/AO.7.000387, 1968.

Eckert, E., von Clarmann, T., Kiefer, M., Stiller, G. P., Lossow, S., Glatthor, N., Degenstein, D. A., Froidevaux, L., GodinBeekmann, S., Leblanc, T., McDermid, S., Pastel, M., Steinbrecht, W., Swart, D. P. J., Walker, K. A., and Bernath, P. F.: Drift-corrected trends and periodic variations in MIPAS IMK/IAA ozone measurements, Atmos. Chem. Phys., 14, 25712589, https://doi.org/10.5194/acp-14-2571-2014, 2014.

Eyring, V., Cionni, I., Bodeker, G. E., Charlton-Perez, A. J., Kinnison, D. E., Scinocca, J. F., Waugh, D. W., Akiyoshi, H., Bekki, S., Chipperfield, M. P., Dameris, M., Dhomse, S., Frith, S. M., Garny, H., Gettelman, A., Kubin, A., Langematz, U., Mancini, E., Marchand, M., Nakamura, T., Oman, L. D., Pawson, S., Pitari, G., Plummer, D. A., Rozanov, E., Shepherd, T. G., Shibata, K., Tian, W., Braesicke, P., Hardiman, S. C., Lamarque, J. F., Morgenstern, O., Pyle, J. A., Smale, D., and Yamashita, Y.: Multimodel assessment of stratospheric ozone return dates and ozone recovery in CCMVal-2 models, Atmos. Chem. Phys., 10, 94519472, https://doi.org/10.5194/acp-10-9451-2010, 2010.

Farman, J. C., Gardiner, B. G., and Shanklin, J. D.: Large losses of total ozone in Antarctica reveal seasonal ClOx/NOx interaction, Nature, 315, 207-210, https://doi.org/10.1038/315207a0, 1985.

Fioletov, V. E., Bodeker, G. E., Miller, A. J., McPeters, R. D., and Stolarski, R.: Global and zonal total ozone variations estimated from ground-based and satellite measurements: 1964-2000, J. Geophys. Res., 107, 4647, https://doi.org/10.1029/2001JD001350, 2002.

Fioletov, V. E., Labow, G., Evans, R., Hare, E. W., Köhler, U., McElroy, C. T., Miyagawa, K., Redondas, A., Savastiouk, V., Shalamyansky, A. M., Staehelin, J., Vanicek, K., and Weber, M.: Performance of the ground-based total ozone network assessed using satellite data, J. Geophys. Res., 113, D14313, https://doi.org/10.1029/2008JD009809, 2008.

Fleming, E. L., Jackman, C. H., Stolarski, R. S., and Douglass, A. R.: A model study of the impact of source gas changes on the stratosphere for 1850-2100, Atmos. Chem. Phys., 11, 85158541, https://doi.org/10.5194/acp-11-8515-2011, 2011.

Frith, S. M., Kramarova, N. A., Stolarski, R. S., McPeters, R. D., Bhartia, P. K., and Labow, G. J.: Recent changes in total column ozone based on the SBUV Version 8.6 Merged Ozone Data Set, J. Geophys. Res.-Atmos., 119, 9735-9751, https://doi.org/10.1002/2014JD021889, 2014.

Frith, S. M., Stolarski, R. S., Kramarova, N. A., and McPeters, R. D.: Estimating uncertainties in the SBUV Version 8.6 merged profile ozone data set, Atmos. Chem. Phys., 17, 14695-14707, https://doi.org/10.5194/acp-17-14695-2017, 2017.

Frossard, L., Rieder, H. E., Ribatet, M., Staehelin, J., Maeder, J. A., Di Rocco, S., Davison, A. C., and Peter, T.: On the relationship between total ozone and atmospheric dynamics and chemistry at mid-latitudes - Part 1: Statistical models and spatial fingerprints of atmospheric dynamics and chemistry, Atmos. Chem. Phys., 13, 147-164, https://doi.org/10.5194/acp-13-147-2013, 2013.

Fusco, A. C. and Salby, M. L.: Interannual Variations of Total Ozone and Their Relationship to Variations of Planetary Wave Activity, J. Climate, 12, 1619-1629, https://doi.org/10.1175/15200442(1999)012<1619:IVOTOA>2.0.CO;2, 1999.

Gray, L. J., Beer, J., Geller, M., Haigh, J. D., Lockwood, M., Matthes, K., Cubasch, U., Fleitmann, D., Harrison, G., Hood, L., Luterbacher, J., Meehl, G. A., Shindell, D., van Geel, B., and White, W.: Solar influences on climate, Rev. Geophys., 48, RG4001, https://doi.org/10.1029/2009RG000282, 2010.

Haenel, F. J., Stiller, G. P., von Clarmann, T., Funke, B., Eckert, E., Glatthor, N., Grabowski, U., Kellmann, S., Kiefer, M., Linden, A., and Reddmann, T.: Reassessment of MIPAS age of air trends and variability, Atmos. Chem. Phys., 15, 13161-13176, https://doi.org/10.5194/acp-15-13161-2015, 2015.

Harris, N. R. P., Kyrö, E., Staehelin, J., Brunner, D., Andersen, S.B., Godin-Beekmann, S., Dhomse, S., Hadjinicolaou, P., Hansen, G., Isaksen, I., Jrrar, A., Karpetchko, A., Kivi, R., Knudsen, B., Krizan, P., Lastovicka, J., Maeder, J., Orsolini, Y., Pyle, J. A., Rex, M., Vanicek, K., Weber, M., Wohltmann, I., Zanis, P., and Zerefos, C.: Ozone trends at northern mid- and high latitudes - a European perspective, Ann. Geophys., 26, 1207-1220, https://doi.org/10.5194/angeo-26-1207-2008, 2008.

Harris, N. R. P., Hassler, B., Tummon, F., Bodeker, G. E., Hubert, D., Petropavlovskikh, I., Steinbrecht, W., Anderson, J., Bhartia, P. K., Boone, C. D., Bourassa, A., Davis, S. M., Degenstein, D., Delcloo, A., Frith, S. M., Froidevaux, L., Godin-Beekmann, S., Jones, N., Kurylo, M. J., Kyrölä, E., Laine, M., Leblanc, S. T., Lambert, J.-C., Liley, B., Mahieu, E., Maycock, A., de Mazière, M., Parrish, A., Querel, R., Rosenlof, K. H., Roth, C., Sioris, C., Staehelin, J., Stolarski, R. S., Stübi, R., Tamminen, J., Vigouroux, C., Walker, K. A., Wang, H. J., Wild, J., and Zawodny, J. M.: Past changes in the vertical distribution of ozone - Part 3: Analysis and interpretation of trends, Atmos. Chem. Phys., 15, 9965-9982, https://doi.org/10.5194/acp15-9965-2015, 2015.

Hofmann, D. J. and Solomon, S.: Ozone destruction through heterogeneous chemistry following the eruption of El Chichón, J. Geophys. Res., 94, 5029, https://doi.org/10.1029/JD094iD04p05029, 1989.

Ivy, D. J., Solomon, S., Kinnison, D., Mills, M. J., Schmidt, A., and Neely, R. R.: The influence of the Calbuco eruption on the 2015 Antarctic ozone hole in a fully coupled chemistry-climate model, Geophys. Res. Lett., 44, 2556-2561, https://doi.org/10.1002/2016GL071925, 2017. 
Kiesewetter, G., Sinnhuber, B.-M., Weber, M., and Burrows, J. P.: Attribution of stratospheric ozone trends to chemistry and transport: a modelling study, Atmos. Chem. Phys., 10, 12073-12089, https://doi.org/10.5194/acp-10-12073-2010, 2010.

Koukouli, M. E., Lerot, C., Granville, J., Goutail, F., Lambert, J.-C., Pommereau, J.-P., Balis, D., Zyrichidou, I., Van Roozendael, M., Coldewey-Egbers, M., Loyola, D., Labow, G., Frith, S., Spurr, R., and Zehner, C.: Evaluating a new homogeneous total ozone climate data record from GOME/ERS-2, SCIAMACHY/Envisat, and GOME-2/MetOp-A, J. Geophys. Res.-Atmos., 120, 1229612312, https://doi.org/10.1002/2015JD023699, 2015.

Kramarova, N. A., Frith, S. M., Bhartia, P. K., McPeters, R. D., Taylor, S. L., Fisher, B. L., Labow, G. J., and DeLand, M. T.: Validation of ozone monthly zonal mean profiles obtained from the version 8.6 Solar Backscatter Ultraviolet algorithm, Atmos. Chem. Phys., 13, 6887-6905, https://doi.org/10.5194/acp13-6887-2013, 2013.

Kuttippurath, J. and Nair, P. J.: The signs of Antarctic ozone hole recovery, Sci. Rep.-UK, 7, 585, https://doi.org/10.1038/s41598017-00722-7, 2017.

Kuttippurath, J., Bodeker, G. E., Roscoe, H. K., and Nair, P. J.: A cautionary note on the use of EESC-based regression analysis for ozone trend studies, Geophys. Res. Lett., 42, 162-168, https://doi.org/10.1002/2014GL062142, 2015.

Labow, G. J., McPeters, R. D., Bhartia, P. K., and Kramarova, N.: A comparison of 40 years of SBUV measurements of column ozone with data from the Dobson/Brewer network, J. Geophys. Res.Atmos., 118, 7370-7378, https://doi.org/10.1002/jgrd.50503, 2013

Lerot, C., Van Roozendael, M., Spurr, R., Loyola, D., ColdeweyEgbers, M., Kochenova, S., van Gent, J., Koukouli, M., Balis, D., Lambert, J.-C., Granville, J., and Zehner, C.: Homogenized total ozone data records from the European sensors GOME/ERS-2, SCIAMACHY/Envisat, and GOME2/MetOp-A, J. Geophys. Res.-Atmos., 119, 1639-1662, https://doi.org/10.1002/2013JD020831, 2014.

Loyola, D. G., Coldewey-Egbers, R. M., Dameris, M., Garny, H., Stenke, A., Van Roozendael, M., Lerot, C., Balis, D., and Koukouli, M.: Global long-term monitoring of the ozone layer - a prerequisite for predictions, Int. J. Remote Sens., 30, 4295-4318, https://doi.org/10.1080/01431160902825016, 2009.

Mäder, J. A., Staehelin, J., Brunner, D., Stahel, W. A., Wohltmann, I., and Peter, T.: Statistical modeling of total ozone: Selection of appropriate explanatory variables, J. Geophys. Res., 112, D11108, https://doi.org/10.1029/2006JD007694, 2007.

Mäder, J. A., Staehelin, J., Peter, T., Brunner, D., Rieder, H. E., and Stahel, W. A.: Evidence for the effectiveness of the Montreal Protocol to protect the ozone layer, Atmos. Chem. Phys., 10, 1216112171, https://doi.org/10.5194/acp-10-12161-2010, 2010.

Manney, G. L. and Lawrence, Z. D.: The major stratospheric final warming in 2016: dispersal of vortex air and termination of Arctic chemical ozone loss, Atmos. Chem. Phys., 16, 15371-15396, https://doi.org/10.5194/acp-16-15371-2016, 2016.

Manney, G. L., Santee, M. L., Rex, M., Livesey, N. J., Pitts, M. C., Veefkind, P., Nash, E. R., Wohltmann, I., Lehmann, R., Froidevaux, L., Poole, L. R., Schoeberl, M. R., Haffner, D. P., Davies, J., Dorokhov, V., Gernandt, H., Johnson, B., Kivi, R., Kyrö, E., Larsen, N., Levelt, P. F., Makshtas, A., McElroy, C. T., Nakajima, H., Parrondo, M. C., Tarasick, D. W., von der Gathen, P., Walker, K. A., and Zinoviev, N. S.: Unprecedented Arctic ozone loss in 2011, Nature, 478, 469-475, https://doi.org/10.1038/nature10556, 2011.

Mason, P. J. and Simmons, A.: Systematic Observation Requirements for Satellite-Based Data Products for Climate 2011 Update, available at: http://www.wmo.int/pages/prog/gcos/ Publications/gcos-154.pdf (last access: 9 February 2018), 2011.

McPeters, R. D., Bhartia, P. K., Haffner, D., Labow, G. J., and Flynn, L.: The version 8.6 SBUV ozone data record: An overview, J. Geophys. Res.-Atmos., 118, 8032-8039, https://doi.org/10.1002/jgrd.50597, 2013.

Mills, M. J., Schmidt, A., Easter, R., Solomon, S., Kinnison, D. E., Ghan, S. J., Neely, R. R., Marsh, D. R., Conley, A., Bardeen, C. G., and Gettelman, A.: Global volcanic aerosol properties derived from emissions, 1990-2014, using CESM1(WACCM), J. Geophys. Res.-Atmos., 121, 2332-2348, https://doi.org/10.1002/2015JD024290, 2016.

Nair, P. J., Godin-Beekmann, S., Kuttippurath, J., Ancellet, G., Goutail, F., Pazmiño, A., Froidevaux, L., Zawodny, J. M., Evans, R. D., Wang, H. J., Anderson, J., and Pastel, M.: Ozone trends derived from the total column and vertical profiles at a northern mid-latitude station, Atmos. Chem. Phys., 13, 10373-10384, https://doi.org/10.5194/acp-13-10373-2013, 2013.

Naujokat, B.: An update of the observed Quasi-Biennial Oscillation of the stratospheric winds over the tropics, J. Atmos. Sci., 43, 1873-1877, https://doi.org/10.1175/15200469(1986)043<1873:AUOTOQ>2.0.CO;2, 1986.

Newman, P. A., Nash, E. R., Kawa, S. R., Montzka, S. A., and Schauffler, S. M.: When will the Antarctic ozone hole recover?, Geophys. Res. Lett., 33, L12814, https://doi.org/10.1029/2005GL025232, 2006.

Newman, P. A., Daniel, J. S., Waugh, D. W., and Nash, E. R.: A new formulation of equivalent effective stratospheric chlorine (EESC), Atmos. Chem. Phys., 7, 4537-4552, https://doi.org/10.5194/acp-7-4537-2007, 2007.

Osprey, S. M., Butchart, N., Knight, J. R., Scaife, A. A., Hamilton, K., Anstey, J. A., Schenzinger, V., and Zhang, C.: An unexpected disruption of the atmospheric quasi-biennial oscillation, Science, 353, 1424-1427, https://doi.org/10.1126/science.aah4156, 2016.

OZONE-CCI-URD: Ozone-cci User Requirement Document (URD), V3.0, available at: http://www.esa-ozone-cci.org/?q= webfm_send/175 (last access: 11 September 2017), 2016.

Pawson, S., Steinbrecht, W., Charlton-Perez, A J Fujiwara, M., Karpechko, A. Y., Petropavlovskikh, I., Urban, J., and Weber, M.: Update on Global Ozone: Past, Present, and Future, in: Scientific Assessment of Ozone Depletion: 2014, World Meteorological Organization, Global Ozone Research and Monitoring Project - Report No. 55, chap. 2, World Meteorological Organization/UNEP, 2014.

Randel, W. J., Wu, F., and Stolarski, R.: Changes in column ozone correlated with the stratospheric EP flux, J. Meteor. Soc. Jpn., 80, 849-862, https://doi.org/10.2151/jmsj.80.849, 2002.

Reinsel, G. C., Miller, A. J., Weatherhead, E. C., Flynn, L. E., Nagatani, R. M., Tiao, G. C., and Wuebbles, D. J.: Trend analysis of total ozone data for turnaround and dynamical contributions, J. Geophys. Res., 110, D16306, https://doi.org/10.1029/2004JD004662, 2005.

Richter, A., Wittrock, F., Weber, M., Beirle, S., Kühl, S., Platt, U., Wagner, T., Wilms-Grabe, W., and Burrows, J. P.: GOME 
Observations of Stratospheric Trace Gas Distributions during the Splitting Vortex Event in the Antarctic Winter of 2002. Part I: Measurements, J. Atmos. Sci., 62, 778-785, https://doi.org/10.1175/JAS-3325.1, 2005.

Salby, M., Titova, E., and Deschamps, L.: Rebound of Antarctic ozone, Geophys. Res. Lett., 38, L09702, https://doi.org/10.1029/2011GL047266, 2011.

Sato, M., Hansen, J. E., McCormick, M. P., and Pollack, J. B.: Stratospheric aerosol optical depths, 1850-1990, J. Geophys. Res., 98, 22987, https://doi.org/10.1029/93JD02553, 1993.

Schnadt Poberaj, C., Staehelin, J., and Brunner, D.: Missing stratospheric ozone decrease at Southern Hemisphere middle latitudes after Mt. Pinatubo: A dynamical perspective, J. Atmos. Sci., 68, 1922-1945, https://doi.org/10.1175/JAS-D-10-05004.1, 2011.

Shepherd, T. G., Plummer, D. A., Scinocca, J. F., Hegglin, M. I., Fioletov, V. E., Reader, M. C., Remsberg, E., von Clarmann, T., and Wang, H. J.: Reconciliation of halogen-induced ozone loss with the total-column ozone record, Nat. Geosci., 7, 443-449, https://doi.org/10.1038/ngeo2155, 2014.

Snow, M., Weber, M., Machol, J., Viereck, R., and Richard, E.: Comparison of Magnesium II core-to-wing ratio observations during solar minimum 23/24, J. Space Weather Spac., 4, A04, https://doi.org/10.1051/swsc/2014001, 2014.

Sofieva, V. F., Kyrölä, E., Laine, M., Tamminen, J., Degenstein, D., Bourassa, A., Roth, C., Zawada, D., Weber, M., Rozanov, A., Rahpoe, N., Stiller, G., Laeng, A., von Clarmann, T., Walker, K. A., Sheese, P., Hubert, D., van Roozendael, M., Zehner, C., Damadeo, R., Zawodny, J., Kramarova, N., and Bhartia, P. K.: Merged SAGE II, Ozone_cci and OMPS ozone profile dataset and evaluation of ozone trends in the stratosphere, Atmos. Chem. Phys., 17, 12533-12552, https://doi.org/10.5194/acp-17-125332017, 2017.

Solomon, P., Barrett, J., Mooney, T., Connor, B., Parrish, A., and Siskind, D. E.: Rise and decline of active chlorine in the stratosphere, Geophys. Res. Lett., 33, L18807, https://doi.org/10.1029/2006GL027029, 2006.

Solomon, S.: Stratospheric ozone depletion: A review of concepts and history, Rev. Geophys., 37, 275-316, https://doi.org/10.1029/1999RG900008, 1999.

Solomon, S., Garcia, R. R., Rowland, F. S., and Wuebbles, D. J.: On the depletion of Antarctic ozone, Nature, 321, 755-758, https://doi.org/10.1038/321755a0, 1986.

Solomon, S., Ivy, D. J., Kinnison, D., Mills, M. J., Neely, R. R., and Schmidt, A.: Emergence of healing in the Antarctic ozone layer, Science, 353, 269-274, https://doi.org/10.1126/science.aae0061, 2016.

Soukharev, B. E. and Hood, L. L.: Solar cycle variation of stratospheric ozone: Multiple regression analysis of long-term satellite data sets and comparisons with models, J. Geophys. Res., 111, D20314, https://doi.org/10.1029/2006JD007107, 2006.

Staehelin, J., Renaud, A., Bader, J., McPeters, R., Viatte, P., Hoegger, B., Bugnion, V., Giroud, M., and Schill, H.: Total ozone series at Arosa (Switzerland): Homogenization and data comparison, J. Geophys. Res.-Atmos., 103, 5827-5841, https://doi.org/10.1029/97JD02402, 1998.

Staehelin, J., Harris, N. R. P., Appenzeller, C., and Eberhard, J.: Ozone trends: A review, Rev. Geophys., 39, 231-290, https://doi.org/10.1029/1999RG000059, 2001.
Steinbrecht, W., Köhler, U., Claude, H., Weber, M., Burrows, J. P., and van der A, R. J.: Very high ozone columns at northern mid-latitudes in 2010, Geophys. Res. Lett., 38, L06803, https://doi.org/10.1029/2010GL046634, 2011.

Steinbrecht, W., Froidevaux, L., Fuller, R., Wang, R., Anderson, J., Roth, C., Bourassa, A., Degenstein, D., Damadeo, R., Zawodny, J., Frith, S., McPeters, R., Bhartia, P., Wild, J., Long, C., Davis, S., Rosenlof, K., Sofieva, V., Walker, K., Rahpoe, N., Rozanov, A., Weber, M., Laeng, A., von Clarmann, T., Stiller, G., Kramarova, N., Godin-Beekmann, S., Leblanc, T., Querel, R., Swart, D., Boyd, I., Hocke, K., Kämpfer, N., Maillard Barras, E., Moreira, L., Nedoluha, G., Vigouroux, C., Blumenstock, T., Schneider, M., García, O., Jones, N., Mahieu, E., Smale, D., Kotkamp, M., Robinson, J., Petropavlovskikh, I., Harris, N., Hassler, B., Hubert, D., and Tummon, F.: An update on ozone profile trends for the period 2000 to 2016, Atmos. Chem. Phys., 17, 1067510690, https://doi.org/10.5194/acp-17-10675-2017, 2017.

Stiller, G. P., von Clarmann, T., Haenel, F., Funke, B., Glatthor, N., Grabowski, U., Kellmann, S., Kiefer, M., Linden, A., Lossow, S., and López-Puertas, M.: Observed temporal evolution of global mean age of stratospheric air for the 2002 to 2010 period, Atmos. Chem. Phys., 12, 3311-3331, https://doi.org/10.5194/acp12-3311-2012, 2012.

Thompson, D. W. J. and Solomon, S.: Interpretation of Recent Southern Hemisphere Climate Change, Science, 296, 895-899, https://doi.org/10.1126/science.1069270, 2002.

Tummon, F., Hassler, B., Harris, N. R. P., Staehelin, J., Steinbrecht, W., Anderson, J., Bodeker, G. E., Bourassa, A., Davis, S. M., Degenstein, D., Frith, S. M., Froidevaux, L., Kyrölä, E., Laine, M., Long, C., Penckwitt, A. A., Sioris, C. E., Rosenlof, K. H., Roth, C., Wang, H.-J., and Wild, J.: Intercomparison of vertically resolved merged satellite ozone data sets: interannual variability and long-term trends, Atmos. Chem. Phys., 15, 3021-3043, https://doi.org/10.5194/acp-15-3021-2015, 2015.

Tweedy, O. V., Kramarova, N. A., Strahan, S. E., Newman, P. A., Coy, L., Randel, W. J., Park, M., Waugh, D. W., and Frith, S. M.: Response of trace gases to the disrupted 2015-2016 quasi-biennial oscillation, Atmos. Chem. Phys., 17, 6813-6823, https://doi.org/10.5194/acp-17-6813-2017, 2017.

Vyushin, D. I., Fioletov, V. E., and Shepherd, T. G.: Impact of long-range correlations on trend detection in total ozone, J. Geophys. Res., 112, D14307, https://doi.org/10.1029/2006JD008168, 2007.

Vyushin, D. I., Shepherd, T. G., and Fioletov, V. E.: On the statistical modeling of persistence in total ozone anomalies, J. Geophys. Res., 115, D16306, https://doi.org/10.1029/2009JD013105, 2010.

Wagner, T., Leue, C., Pfeilsticker, K., and Platt, U.: Monitoring of the stratospheric chlorine activation by Global Ozone Monitoring Experiment (GOME) OClO measurements in the austral and boreal winters 1995 through 1999, J. Geophys. Res.-Atmos., 106, 4971-4986, https://doi.org/10.1029/2000JD900458, 2001.

Weatherhead, E. C., Reinsel, G. C., Tiao, G. C., Meng, X.-L., Choi, D., Cheang, W.-K., Keller, T., DeLuisi, J., Wuebbles, D. J., Kerr, J. B., Miller, A. J., Oltmans, S. J., and Frederick, J. E.: Factors affecting the detection of trends: Statistical considerations and applications to environmental data, J. Geophys. Res.-Atmos., 103, 17149-17161, https://doi.org/10.1029/98JD00995, 1998. 
Weatherhead, E. C., Reinsel, G. C., Tiao, G. C., Jackman, C. H., Bishop, L., Frith, S. M. H., DeLuisi, J., Keller, T., Oltmans, S. J., Fleming, E. L., Wuebbles, D. J., Kerr, J. B., Miller, A. J., Herman, J., McPeters, R., Nagatani, R. M., and Frederick, J. E.: Detecting the recovery of total column ozone, J. Geophys. Res.-Atmos., 105, 22201-22210, https://doi.org/10.1029/2000JD900063, 2000.

Weatherhead, E. C., Harder, J., Araujo-Pradere, E. A., Bodeker, G., English, J. M., Flynn, L. E., Frith, S. M., Lazo, J. K., Pilewskie, P., Weber, M., and Woods, T. N.: How long do satellites need to overlap? Evaluation of climate data stability from overlapping satellite records, Atmos. Chem. Phys., 17, 15069-15093, https://doi.org/10.5194/acp-17-15069-2017, 2017.

Weber, M., Lamsal, L. N., Coldewey-Egbers, M., Bramstedt, K., and Burrows, J. P.: Pole-to-pole validation of GOME WFDOAS total ozone with groundbased data, Atmos. Chem. Phys., 5, 1341-1355, https://doi.org/10.5194/acp-5-1341-2005, 2005.

Weber, M., Dikty, S., Burrows, J. P., Garny, H., Dameris, M., Kubin, A., Abalichin, J., and Langematz, U.: The Brewer-Dobson circulation and total ozone from seasonal to decadal time scales, Atmos. Chem. Phys., 11, 11221-11235, https://doi.org/10.5194/acp-11-11221-2011, 2011.

Weber, M., Steinbrecht, W., Roth, C., Coldewey-Egbers, M., Degenstein, D., Fioletov, V. E., Frith, S. M., Froidevaux, L., de Laat, J., Long, C. S., Loyola, D., and Wild, J. D.: [Global Climate] Stratospheric ozone [in "State of the Climate in 2015"], B. Am. Meteorol. Soc., 97, S49-S51, https://doi.org/10.1175/2016BAMSStateoftheClimate.1, 2016.
Wild, J. D. and Long, C. S.: A coherent ozone profile dataset from SBUV, SBUV/2: 1979 to 2016, in preparation, 2017.

Wolter, K. and Timlin, M. S.: El Niño/Southern Oscillation behaviour since 1871 as diagnosed in an extended multivariate ENSO index (MEI.ext), Int. J. Climatol., 31, 1074-1087, https://doi.org/10.1002/joc.2336, 2011.

Zhang, J., Xie, F., Tian, W., Han, Y., Zhang, K., Qi, Y., Chipperfield, M., Feng, W., Huang, J., and Shu, J.: Influence of the Arctic Oscillation on the Vertical Distribution of Wintertime Ozone in the Stratosphere and Upper Troposphere over the Northern Hemisphere, J. Climate, 30, 2905-2919, https://doi.org/10.1175/JCLID-16-0651.1, 2017.

Zubov, V., Rozanov, E., Egorova, T., Karol, I., and Schmutz, W.: Role of external factors in the evolution of the ozone layer and stratospheric circulation in 21st century, Atmos. Chem. Phys., 13, 4697-4706, https://doi.org/10.5194/acp-134697-2013, 2013.

Zvyagintsev, A. M., Vargin, P. N., and Peshin, S.: Total ozone variations and trends during the period 1979-2014, Atmos. Oceanic Opt., 28, 575-584, https://doi.org/10.1134/S1024856015060196, 2015. 